M. S. Žebec, I. Crnko, V. Palavra, D. Sumpor*

\title{
POKAZATELJI DINAMIKE FUNKCIONIRANJA SELEKTIVNE PAŽNJE HRVATSKIH STROJOVOĐA I NJIHOVE DOBNE RAZLIKE
}

UDK 656.62:613.98]:159.952

PRIMLJENO: 31.1 .2017$.

PRIHVAĆENO: 7.7 .2017

\begin{abstract}
SAŽETAK: Istraživanja starosnih promjena dinamike funkcioniranja sustava selektivne pažnje (SP) vrlo su rijetka, a posebice kod profesionalnih vozača. S obzirom na to da su posljedice funkcioniranja SP strojovođa za sigurnost prometa iznimno velike, smatra se važnim istražiti učinke starenja na tri pokazatelja dinamike funkcioniranja sustava SP (prosječna učinkovitost, stabilnost, otpornost prema djelovanju nepovoljnih čimbenika), a s obzirom na različite mjere SP. Istraživanje je provedeno upotrebom dvije vremenski ograničene forme Stroop testa: prve - verbalne i neobojene (leksičke), te druge - verbalne i obojene papir-olovka forme. Obje forme sastojale su se od dva dijela/komponente: s inkongruentnim podražajima (koji su mjerili SP i brzinu obrade podataka, tj. BOP) te s neutralnim podražajima (koji su mjerili samo BOP). Sudionici su bili muški strojovođe Hrvatskih željeznica, u dobi od 25 do 59 godina, neravnomjerno raspodijeljeni u 4 dobne skupine, određene specifičnim funkcionalnim karakteristikama profesionalnih vozača. Prvu je popunilo 50 sudionika, a 52 njih popunilo je drugu formu testa. Sudionikov zadatak bio je da precrta što je moguće više ciljnih riječi u kontekstu distraktora tijekom 60 sekundi (pri čemu je distrakcija bila intenzivnija kod inkongruentnih podražaja). Sva tri pokazatelja dinamike funkcioniranja SP izražena su kao kompoziti objektivnih mjera dvije sastavnice Stroop testa te pokazuju jednoznačan odnos s izraženošću pripadnog konstrukta, dok niske međusobne korelacije ukazuju na njihovu različitost. Uz iznimku relativne pozicije 1. pogreške - koja se zbog iznimno malog varijabiliteta nije mogla iskoristiti kao mjera otpornosti - većina preostalih pokazatelja dinamike u odabranom uzorku hrvatskih strojovođa pokazala je dobra statistička svojstva i teorijsku utemeljenost. Dobne promjene sva tri pokazatelja dinamike SP odražavaju nelinearan trend koji je samo dijelom u skladu s uvriježenim očekivanjima, te se pokazao statistički značajnim samo kod otpornosti SP u obojenoj verziji Stroop testa. Premda navedeni trendovi dobnih promjena najvećim dijelom nisu bili značajni, ipak je prosječna učinkovitost i stabilnost SP u obojenoj verziji testa pokazala statistički značajno drugačiji oblik dobnih promjena nego u leksičkoj verziji testa. Analize su dodatno pokazale kako je prosječna učinkovitost SP značajno veća u Stroop testu s prometno relevantnim bojama, a sličan trend - premda neznačajan - pokazuju i stabilnost te otpornost SP djelovanju nepovoljnih čimbenika. Dobiveni rezultati, uz određeni oprez zbog nedostatka mjerenja kontrolne skupine i drugih metodoloških ograničenja specifičnih za primijenjena istraživanja, tumače se specifičnim iskustvom strojovođa te su raspravljeni u sklopu teorija kognitivnog starenja opće populacije, ali s implikacijama na proces starenja strojovođa i njegove posljedice-posebice u području sigurnosti prometa.
\end{abstract}

Ključne riječi: selektivna pažnja, pokazatelji dinamike funkcioniranja, proces starenja, strojovođe

\section{UVOD}

Dobne promjene selektivne pažnje (SP) imaju značajne posljedice na kognitivno funkcioniranje

*Doc. dr. sc. Mislav Stjepan Žebec, (mzebec@hrstud.hr), Hrvatski studiji, Borongajska cesta 83 d, 10000 Zagreb, Ines Crnko, Vedrana Palavra, doc. dr. sc. Davor Sumpor, Fakultet prometnih znanosti, Vukelićeva 4, 10000 Zagreb. osoba u zreloj i starijoj dobi jer se radi o ključnom obliku pažnje bez kojeg drugi kognitivni procesi ne bi mogli uspješno funkcionirati. Naime, SP predstavlja skup kognitivnih procesa s pripadnom neuralnom osnovom čija svrha je selektivno primanje određenih podražaja iz dane podražajne situacije uz istovremeno inhibiranje drugih podražaja iz te situacije, irelevantnih za njezino rješavanje (Sternberg, 2005.). 
SP je uglavnom mjerena Stroop testom koji se sastoji od inkongruentne i neutralne komponente, a pokazao se kao stabilna mjera prosječne učinkovitosti inhibitornih mehanizama u velikom broju istraživanja (Ludwig et al., 2010., MacLeod, 1991., Ben-David i Schneider, 2009.). Uradak u svim Stroop zadacima ima istu racionalu: inhibirati perceptivno dominantniji distraktor te odgovoriti na manje dominantan ciljni podražaj (primjerice, imenovati boju kojom su napisana slova neke riječi, dok se istovremeno ignorira značenje riječi); (Jensen $i$ Rohwer, 1966.). Interferencija više i manje dominantnog odgovora izazvana je nepodudarnošću podražaja (boje i značenja) i manjeg je intenziteta kada su inhibicijski procesi jači, odnosno kada je SP veća. Procjena prosječne učinkovitosti inhibitornog sustava provodi se obično usporedbom izvedbe na inkongruentnoj i neutralnoj komponenti Stroop testa (pri čemu se izvedba u neutralnoj komponenti mjeri, primjerice, imenovanjem boje obojene mrlje) i obično je izražena Stroop učinkom: razlikom između latencije odgovora i/ili broja netočnih odgovora u inkongruentnoj i neutralnoj komponenti (Ludwig et al., 2010.). Djelovanje dobi na Stroop učinak kao mjeru SP višestruko je ispitivano u općoj populaciji te je generalno potvrđen pad učinkovitosti SP zbog starenja (Mutter et al., 2005., Ben-David i Schneider, 2009., Brink i McDowd, 1999., Davidson et al., 2003.). Točnije, većina istraživanja uspoređivala je dvije grupe, mlađu (prosječna dob 25 godina) i stariju (prosječna dob 65 godina) te se pokazalo da je slabija SP, odnosno izraženija interferencija, prisutnija kod starijih osoba, s obzirom da stariji slabije kontroliraju aktivaciju proturječnih informacija iz riječi. Postoje različita objašnjenja za dobno povećanje Stroop učinka, no najprihvaćenije je ono o generalnom kognitivnom usporavanju i senzornim gubitcima s dobi, uključujući deterioraciju u percepciji boja (Ben-David i Schneider, 2009.). Također, fMRI istraživanja otkrila su da se mlađe i starije odrasle osobe razlikuju u obrascima neuralne aktivnosti povezanima s učinkom na Stroop testu gdje stariji pokazuju manje opsežnu aktivnost u području mozga poznatom kao dorsolateralni prefrontalni korteks (Davidson et al., 2003.).
No, postavlja se pitanje je li prosječna učinkovitost procesa SP dovoljno osjetljiva mjera za cjelovitiji opis funkcioniranja tih kognitivnih procesa i njihovih dobnih promjena, ili treba sagledati različita obilježja tog funkcioniranja - poput (ne)stabilnosti, izdržljivosti, prilagodljivosti, potencijala/brzine, ili slabosti/nepouzdanosti/ neotpornosti djelovanju nepovoljnih čimbenika - koje u svojem zbroju daju prosječnu učinkovitost, a koje mogu različito djelovati na nju?

Podaci o dobnim razlikama različitih, neprosječnih mjera funkcioniranja nekog kognitivnog procesa, ili pripadnog kognitivnog podsustava, uglavnom se svode na istraživanja dobnih promjena stabilnosti kognitivnog funkcioniranja putem intraindividualnog varijabiliteta u testovima brzine obrade podataka (BOP); (Adelman et al., 2016., MacDonald et al., 2003., Myerson et al., 2007.), a rijetka su istraživanja intraindividualnog varijabiliteta složenijih kognitivnih funkcija (Drenovac, 2009., Drenovac i Drenovac, 1976.). Nalazi o dobnim promjenama različitih, neprosječnih obilježja funkcioniranja sustava SP vrlo su malobrojni (West et al., 2002.), premda studije o stabilnosti SP postoje i uglavnom su kliničke naravi (Castellanos et al., 2005., Lutz et al., 2009.).

Činjenica da je starenje obilježeno degenerativnim procesima, ali i drugim promjenama - kako na fiziološkom, tako i na bihevioralnom planu (kognitivne sposobnosti, osobnost, motivacija za rad) - ima značajne posljedice za profesionalno funkcioniranje pojedinaca, te generira niz pitanja za cijelo društvo (Kanfer i Ackerman, 2004.). Takva pitanja posebno su važna za sektor prijevoza zbog njihovih zahtjevnih zadataka i radnog vremena ovisnog o rasporedu (Popkin et al., 2008.) koji se uvelike mogu odraziti na efikasnost i sigurnost prijevoza robe i putnika. Uzimajući u obzir prethodno spomenutu važnost SP za sve kognitivne funkcije, pa time i za izvedbu posla, svrha ovog istraživanja nameće se sama po sebi. Vid i pažnja vrlo su važni za učinak strojovođe (Kanfer i Ackerman, 2004.) koji imaju zahtjevne radne uvjete i veliku odgovornost za sigurnost prometa. Koliko se zna, istraživanja dobnih promjena SP, mjerenih Stroop testom u 
populaciji strojovođa, tek su u početnoj fazi (posebice u Republici Hrvatskoj) te su i dalje koristila samo klasične mjere prosječne učinkovitosti SP (Žebec et al., 2016.). Korištenje drugačijih mjera prosječne učinkovitosti selektivne pažnje (PESP), ali i drugih pokazatelja dinamike funkcioniranja sustava SP - poput stabilnosti (SSP) i otpornosti sustava SP (OSP) ka djelovanju nepovoljnih čimbenika - može dati sveobuhvatniji uvid u starosne promjene sustava SP hrvatskih strojovođa. Podaci o pokazateljima dinamike funkcioniranja SP i pripadnim dobnim promjenama strojovođa mogu pomoći stručnjacima u maksimiziranju prometne sigurnosti, kako za vozače tako i za putnike, osmišljavajući moguće preventivne intervencije.

\section{CILJ I HIPOTEZE}

Cilj istraživanja bio je ispitati učinke starenja na tri novouvedena pokazatelja dinamike funkcioniranja sustava SP - PESP, SSP i OSP - kod hrvatskih strojovođa, podijeljenih u četiri dobne kategorije (određene specifičnim funkcionalnim osobinama profesionalnih vozača) iz raspona od 25 do 59 godina, uzimajući pri tome u obzir sadrže li SP-mjere prometno relevantne boje, ili ne.

1. Hipoteza: Testovi selektivne pažnje, izvedeni u obliku papir-olovka testova brzine, daju tri valjana pokazatelja dinamike funkcioniranja SP kod hrvatskih strojovođa različite dobi:

a) PESP, izraženu odnosom prosječnog vremena rješavanja inkongruentne $i$ neutralne komponente Stroop-zadatka,

b) SSP, izraženu odnosom intraindividualnog varijabiliteta rješavanja inkongruentne i neutralne komponente Stroop-testa,

c) OSP djelovanju nepovoljnih čimbeni$k a$, izraženu odnosom relativne pozicije prve pogreške u inkongruentnoj i neutralnoj komponenti Stroop-testa, te odnosom relativne pozicije prve omaške $\mathrm{u}$ inkongruentnoj i neutralnoj komponenti Stroop-testa.
2. Hipoteza: Dobne razlike u PESP i SSP te dobne razlike u OSP, pokazuju nelinearne promjene kroz četiri dobne kategorije određene specifičnim osobinama profesionalnih vozača.

3. Hipoteza: Dobne razlike u PESP i SSP te dobne razlike u OSP razlikuju se ovisno o tome sadrže li prometno relevantne boje, ili ne.

4. Hipoteza: Statistička svojstva i dobne promjene tri pokazatelja dinamike funkcioniranja SP opravdavaju primjenu tih pokazatelja te ukazuju na određene specifičnosti hrvatskih strojovođa u odnosu na opću populaciju promatrane dobi, koje se mogu pripisati specifičnostima radnog mjesta te djelomice utjecati.

\section{METODA}

\section{Sudionici}

Sudionici su 102 muških strojovođa, u dobi od 25 do 59 godina starosti, zaposleni u Hrvatskim željeznicama. Kako je istraživanje provedeno u dva dijela (srpanj i kraj rujna 2015. godine), 50 sudionika $\left(M_{d o b}=40,9, S D_{d o b}=9,35\right)$ bilo je uključeno u prvom, a $52\left(M_{d o b}=41,3, S D_{d o b}=7,26\right)$ u drugom dijelu istraživanja. Sudionici su bili nejednako raspodijeljeni u 4 dobne skupine (2029, 30-39, 40-49 i 50-59 godina) izdvojene s obzirom na specifične funkcionalne karakteristike profesionalnih vozača, čije su starosne promjene evidentirane u analizama statističkog rizika za nastanak nesreća ovisno o navršenoj dobi vozača već na razini petogodišnjih dobnih intervala (Broach et al., 2003., Ryan et al., 2003.), dok znanstvena literatura o starosnim promjenama vremena reakcije upućuje na desetogodišnje intervale, počevši od 20 godina starosti (Woodson et al., 1992.).

\section{Instrumenti}

$U$ dva dijela istraživanja bile su uključene dvije papir-olovka forme testa SP, predstavljajući zapravo dvije različite operacionalizacije Stroop testa (s prometno relevantnim bojama i bez njih) 
koji se primjenjuje u vrlo kratkom vremenu te zbog toga pripada kategoriji testova brzine. Obje forme sastojale su se od inkongruentne i neutralne komponente koje su odvojeno dane na ispunjavanje neposredno jedna nakon druge (pri čemu je neutralna komponenta Stroop testa obično predstavljala standardni test perceptivne brzine).

Komponenta $s$ inkongruentnim podražajima u prvoj operacionalizaciji SP inkongruentna je forma (tzv. "incongruence condition") leksičke verzije Stroop testa (Rimac et al., 2006.). Sastoji se od 232 riječi od kojih je 50 \% riječi "veliko" i ostalih 50 \% riječi "maleno". Također, 50 \% riječi nasumično je napisano velikim tiskanim slovima dok je ostatak pisan malim slovima. Njihov sadržaj i prostorni raspored varirani su nasumično unutar redova i stranica. Zadatak sudionika bio je precrtati jednom (kosom) crtom što više ciljne riječi "maleno" unutar 60 sekundi, bez preskakanja riječi i redova, bez obzira je li ciljna riječ pisana malim ili velikim slovima.

Komponentna s neutralnim podražajima prve operacionalizacije SP neutralna je forma leksičke verzije Stroop testa. Sastoji se od $448^{1}$ riječi gdje je 50 \% riječi "veliko" i ostalih 50 \% riječi "maleno". Sve su riječi pisane malim tiskanim slovima, a njihov sadržaj i prostorni raspored nasumično variraju kroz retke i stranice testa. Zadatak sudionika bio je precrtati jednom (kosom) crtom što više ciljne riječi "maleno" u 60 sekundi, bez preskakanja riječi ili redova.

Metrijska obilježja izvedena su iz ukupnog broja točno precrtanih ciljnih riječi (koji je ključna varijabla ovakvih brzinskih testova SP jer se iz nje izvodi Stroop-učinak kao ključna mjera selektivne pažnje), premda je, kao izlazne mjere moguće registrirati i druge varijable (broj pogrešaka, omaški, te slično).

Preliminarna, dvokratna primjena ove operacionalizacije Stroop testa na uzorku od 127 studenata preddiplomskog studija psihologije $\mathrm{Hr}$ vatskih studija Sveučilišta u Zagrebu ukazuje na dobra metrijska obilježja ovog testa, posebice kad

\footnotetext{
1 Veći broj podažaja u neutralnoj formi bio je potreban s obzirom na to da je veći broj takvih podražaja prekrižen u usporedbi s inkongruentnom formom
}

se u obzir uzme da su podaci dobiveni na uzorku koji je selekcioniran prema kognitivnim varijablama (zbog čega je sužen varijabilitet rezultata).

Objektivnost testa visoko je zadovoljena jer je test proveden u standardnim uvjetima skupnog testiranja, a rezultati kodirani prema unaprijed određenom ključu.

Osjetljivost neutralne komponente nešto je veća od osjetljivosti inkongruentne komponente jer - premda su im koeficijenti varijabilnosti podjednaki (CV-neutralna=12.03\%; CV-inkongruentna $=12.83)$ - raspon ostvarenih rezultata nešto je veći kod neutralne $(\min =78$, maks $=142)$ nego li inkongruentne komponente $(\min =62$, maks=116). Varijabiliteti jesu malo suženi u odnosu na prosječni rezultat (optimalna vrijednost CV bila bi $20 \%$ ), no niti kod jedne komponente nije ostvaren učinak poda i stropa te se može zaključiti da je osjetljivost obiju komponenti testa visoka. Pored toga, i normalan oblik raspodjela dodatno upućuje na diskriminativnost (ali i na konstruktnu valjanost) obje komponente testa: Kolmogorov-Smirnov Z(inkongruentno) $=0.666$, $\mathrm{p}=0.766$; Kolmogorov-Smirnov $Z$ (neutralno)= 0.566, $\mathrm{p}=0.906)$.

S obzirom na narav testova brzine (u kojima skoro svi rješavani zadaci imaju vrijednost 1 , dok vrijednost 0 najvećim dijelom imaju oni koji se nisu niti stigli rješavati), jedini opravdani pokazatelj pouzdanosti jest indeks test-retest pouzdanost. $U$ dvije primjene (s razmakom od približno 3 mjeseca) obje komponente korištenog Stroop testa dobiveni pokazatelji test-retest pouzdanosti su $\operatorname{rxx}($ inkongruentno $)=0.862 \mathrm{ir}_{\mathrm{xx}}$ (neutralno $)=0.853$ - što ukazuje na dobru pouzdanost instrumenta.

Sadržajna valjanost ovog testa SP je visoka jer je test vrlo sličan obojenoj i drugim verzijama Stroop testa (osim po samom sadržaju) koje su široko prihvaćene mjere SP (Brink i McDowd, 1999., Christ et al., 2001.). Metrijska obilježja ovog leksičkog testa SP u populaciji hrvatskih strojovođa dijelom su vidljiva iz analize empirijske valjanosti PESP, SSP i OSP (posebice tablice 1, 2 i 3 Rezultata).

U drugoj („obojenoj“) operacionalizaciji SP (primijenjenoj u drugom dijelu istraživanja) 
inkongruentnu komponentu testa predstavlja inkongruentna forma (tzv. "incongruence condition") papir-olovka Stroop testa koja se često naziva "verzija u blokovima" (Ludwig i sur., 2010.). Sastoji se od 232 riječi pisanih malim tiskanim slovima, $50 \%$ njih je riječ "crveno" a ostalih 50 \% riječ "zeleno". Također, 50 \% obje riječi je nasumično printano u crvenoj boji, odnosno 50 \% u zelenoj boji. Njihov sadržaj i prostorni raspored ponovno variraju nesustavno unutar redova i stranica testa. Zadatak sudionika bio je unutar 60 sekundi precrtati jednom (kosom) crtom što više ciljne riječi "zeleno", bez preskakanja riječi ili redova bez obzira je li ciljna riječ napisana crvenom ili zelenom bojom.

Komponenta s neutralnim podražajima druge operacionalizacije SP je neutralna forma "verzije u blokovima" (tzv. "reading condition") Stroop testa. Sastoji se od 448 riječi od kojih je 50 \% riječi "crveno" i ostatak je ponovno riječ "zeleno" ali su ovog puta sve riječi printane u crnoj boji i pisane malim slovima. Njihov sadržaj i prostorni raspored postavljen je nasumično unutar stranice i retka, a zadatak sudionika bio je precrtati jednom (kosom) crtom što je moguće više ciljne riječi "zeleno" u 60 sekundi, bez preskakanja riječi ili redova.

Metrijska obilježja dvije komponente ove "obojene" operacionalizacije Stroop testa, izvedene iz ukupnog broja točno precrtanih ciljnih riječi i dobivene u preliminarnoj primjeni instrumenta na studentskom uzorku, također se mogu smatrati dobrima (zbog selekcioniranosti uzorka), premda su pokazatelji test-retest pouzdanosti nešto niži: $r_{x x}$ (inkongruentno) $=0.775$ i $r_{x x}$ (neutralno $)=0.795$. Naime, objektivnost $i$ sadržajna valjanost, slično kao i kod leksičkog SP testa, mogu se smatrati visokima, a osjetljivost dobrom - premda nešto višom kod neutralne $(C V=12.29 \%, \min =72$, maks $=148)$, nego li kod inkongruentne $(\mathrm{CV}=10.72 \%, \min =72$, maks=116) komponente. Normalan oblik raspodjela dodatno upućuje na diskriminativnost (ali i na konstruktnu valjanost) obje komponente testa: Kolmogorov-Smirnov Z(inkongruentno $)=0.686$, $\mathrm{p}=0.735$; Kolmogorov-Smirnov Z(neutralno)= $0.589, p=0.879$. Također, metrijska obilježja ovog "obojenog" testa SP u populaciji hrvatskih strojovođa dijelom su vidljiva iz analize empirijske valjanosti PESP, SSP i OSP (tablice 1, 2 i 3 Rezultata).

Konačno, u vrednovanju postupka mjerenja potrebno je osvrnuti se na eventualnu prisutnost strategije brzog odgovaranja na račun točnosti. Ona je razvidna iz korelacija vremena potrebnog za precrtavanje ciljne riječi i ukupnog broja netočnih odgovora u testu (omaški i pogrešaka): ako je ta korelacija značajna i negativna, onda ova strategija postoji te pojedinci pokazuju tendenciju ka kraćem vremenu odgovaranja zbog činjenja većeg broja netočnih odgovora. Korelacijska analiza vremena precrtavanja ciljne riječi i broja netočnih odgovora u obje komponente (inkongruentne i neutralne) iz obiju verzija Stroop testa (leksičke i obojene) pokazala je da u svakoj od njih postoji tendencija negativnoj korelaciji, no ona je niska i statistički neznačajna $(p>0.05)$ : $r$ (leksička-inkongruentna) $=-0.160 ; r$ (leksičkaneutralna $)=-0.098 ;$ r $($ obojena-inkongruentna $)=$ $-0.221 ; r(o b o j e n a-n e u t r a l n a)=-0.068$.

\section{Postupak}

Istraživanje je provedeno u službenim prostorijama Hrvatskih željeznica na Glavnom kolodvoru u Zagrebu, tijekom srpnja i rujna 2015. godine, a uz prethodni pristanak sudionika. Ono je dio opsežnijeg istraživanja koje osim testa SP uključuje nekoliko drugih psiholoških mjera kao i skup antropometrijskih varijabli. lako je originalno planirano testiranje u manjim grupama (do 10 sudionika), ono je ipak provedeno većinski individualno (prije ili nakon radne smjene sudionika) ${ }^{2}$.

Nakon uzimanja osobnih podataka sudionika, istraživač je prvotno pročitao standardizirane upute za rješavanje testa i objasnio zadatak sudionicima pomoću primjera. Nakon što je utvrđeno razumijevanje uputa i spremnost na testiranje, sudionici su rješavali prvu komponentu testa u zadanom vremenu od $60 \mathrm{~s}$. Dvije komponente testa (inkongruentna i neutralna) rotirane

2 Uvid u protokole mjerenja ukazao je da ne postoji sustavni odnos između dobi sudionika i testiranja s obzirom na to je li ono provedeno prije radne smjene sudionika ili poslije nje. Stoga se nije smatralo važnim za istraživačke hipoteze testirati mogući utjecaj vremena testiranja na rezultate. 
su među sudionicima, kako bi se izbjegle prijetnje u vezi s ponovljenim mjerenjima. Istraživač je kontrolirao vrijeme koristeći zaporni sat te je registrirao potencijalne smetnje kao i ostale relevantne čimbenike u procesu mjerenja. Nakon što je prva komponenta testa riješena sudionici su odmah rješavali drugu, koristeći istu proceduru. Po završetku rješavanja svih ostalih psihologijskih testova, materijali su sakupljeni $\mathrm{i}$ istraživači su odgovarali na moguća pitanja sudionika u vezi s cjelokupnim istraživanjem. Uvjeti testiranja nisu bili laboratorijski primarno zbog niske, ali promjenjive razine buke u pozadini, te zbog povremenih ulazaka trećih osoba u prostor testiranja. Međutim, analize procedure mjerenja ukazale su na nisku i nesustavnu prisutnost smetnji mjerenju koje nisu povezane s dobi sudionika (koja je glavna nezavisna varijabla osmišljenog istraživanja).

\section{Odredivanje pokazatelja PESP, SSP i OSP}

Tri mjere dinamike funkcioniranja sustava SP, koje su predmet ovog istraživanja, definirane su na sljedeći način:

1. $\mathrm{PESP}=[60 \mathrm{~s} / \mathrm{n}$ (točno precrtanih ciljnih riječi, INKONGRUENTNO)] / [60s/n(točno precrtanih ciljnih riječi, NEUTRALNO)] = $=\mathrm{n}$ (točno precrtanih ciljnih riječi, NEUTRALNO) / n(točno precrtanih ciljnih rijeČi, INKONGRUENTNO)

2. $\mathrm{SSP}=\mathrm{SD}$ [odgovori u svim zadacima, $\mathbf{I N}$ KONGRUENTNO] / SD[odgovori u svim zadacima, NEUTRALNO]

3. OSP $=\operatorname{RedBr}[$ Zadatak 1. omaške/pogreške, INKONGRUENTNO] - RedBr[Zadatak 1. omaške/pogreške, NEUTRALNO]

S obzirom na prvu hipotezu istraživanja, podrobniji opis ovih mjera dinamike funkcioniranja sustava SP dan je u prvom dijelu Rezultata i Rasprave.

\section{REZULTATI}

\section{Empirijska valjanost PESP, SSP i OSP kod hrvatskih strojovođa}

U cilju empirijskog provjeravanja valjanosti tri pokazatelja dinamike funkcioniranja susta- va SP na populaciji hrvatskih strojovođa (PESP, SSP i OSP nepovoljnim čimbenicima) razmatra se njihova sadržajna valjanost (metodološka opravdanost definicije tih konstrukata), diskriminativnost (statistička obilježja raspodjele dobivenih rezultata), te međusobne i korelacije $s$ drugim relevantnim mjerama kognitivnog funkcioniranja.

\section{PESP}

PESP, izražena omjerom prosječnog vremena rješavanja inkongruentne i neutralne verzije Stroop zadatka, može se smatrati inverznom mjerom učinkovitosti SP jer, što je omjer veći, to je sklonost interferenciji veća, a SP slabija.

Da je valjano odabrana govori i činjenica da je visoko povezana s uvriježenom mjerom učinkovitosti SP izraženom razlikom prosječnog vremena rješavanja inkongruentne $\mathrm{i}$ neutralne verzije Stroop zadatka (u leksičkoj verziji testa omjerni izračun učinkovitosti i izračun putem razlike pokazuju povezanost $r=0.878, p<0.001$, u obojenoj verziji testa ta dva izračuna pokazuju povezanost $r=0.967, p<0.001)$. Razlog za nekorištenje uvriježene mjere interferencije, odnosno učinkovitosti SP je činjenica da ta mjera ima potencijalno smanjenu pouzdanost jer u sebi sadrži zamjetan udio varijance pogreške, $s$ obzirom na to da je nastala oduzimanjem dvije varijable koje su međusobno visoko korelirane (u leksičkoj verziji testa povezanost prosječnog vremena rješavanja zadatka interferirajuće i neutralne verzije Stroop testa iznosi $r=0.895$, $p<0.001$, u obojenoj verziji testa $r=0.828$, $p<0.001)$. Korištenjem omjera najvećim dijelom izbjegava se navedena prijetnja povećane nepouzdanosti.

Valjanost odabira ove mjere učinkovitosti SP sugeriraju statistička svojstva raspodjele strojovođa s obzirom na tu mjeru. Statistički ne odstupa od normalne raspodjele niti na jednoj promatranoj dobnoj skupini i premda je malo suženog varijabiliteta, on je homogen na svim dobnim skupinama (leksička verzija: $\mathrm{F}=1.284, d f_{1}=3, d f_{2}=46, p=0.291$; obojena verzija: $\left.F=1.924, d f_{1}=3, d f_{2}=48, p=0.138\right)$. 
Tablica 1. Deskriptivna statistika i rezultati Kolmogorov-Smirnov testa normaliteta za PESP

Table 1. Descriptive statistics and results of Kolmogorov-Sirnov normality test for SAAE

\begin{tabular}{|c|c|c|c|c|c|c|c|c|}
\hline & $\begin{array}{c}\text { Dobne } \\
\text { skupine }\end{array}$ & $N$ & $M$ & SD & $\min -\max$ & $Z_{\text {skew }}$ & $K S_{z}$ & $\mathrm{CV}$ \\
\hline \multirow{4}{*}{$\begin{array}{l}\text { (Stroop- } \\
\text { Time/ } \\
\text { BopTime) } \\
\text { leksička }\end{array}$} & 20-29 & 9 & 1.31 & 0.10 & $1.20-1.50$ & 1.30 & 0,610 & 7.71 \\
\hline & 30-39 & 13 & 1.22 & 0.15 & $0.95-1.43$ & -0.18 & 0.522 & 12.30 \\
\hline & $40-49$ & 17 & 1.23 & 0.11 & $1.05-1.40$ & -0.00 & 0.381 & 9.02 \\
\hline & 50-59 & 11 & 1.30 & 0.10 & $1.13-1.47$ & 0.35 & 0.582 & 7.77 \\
\hline \multirow{4}{*}{$\begin{array}{l}\text { (Stroop- } \\
\text { Time/ } \\
\text { BopTime) } \\
\text { obojena }\end{array}$} & $20-29$ & 2 & 0.88 & 0.20 & $0.74-1.02$ & / & I & 22.5 \\
\hline & 30-39 & 23 & 1.09 & 0.10 & $1.95-1.35$ & 1.49 & 0.597 & 9.36 \\
\hline & $40-49$ & 17 & 1.12 & 0.12 & $0.97-1.36$ & 0.87 & 0.806 & 10.45 \\
\hline & $50-59$ & 10 & 1.13 & 0.17 & $0.83-1.34$ & -0.62 & 0.474 & 14.78 \\
\hline
\end{tabular}

\section{SSP}

SSP, izražena omjerom pojedinčevog intraindividualnog varijabiliteta $u$ inkongruentnoj i neutralnoj komponenti Stroop testa, također je negativna mjera stabilnosti sustava SP, jer što je navedeni omjer veći, to je veća relativna nestabilnost $\mathrm{SP}, \mathrm{s}$ obzirom na to da veća SD ukazuje na veće pojedinčevo variranje u rješavanju zadataka testa.

Napomena: ponovno nije korištena razlika SD inkongruentne i SD neutralne komponente jer se u njoj gubi zamjetan dio zajedničke varijance dviju varijabli (s obzirom da je njihova međusobna povezanost u leksičkoj verziji testa $r=0.611, p<0.001$, a u obojenoj verziji testa $r=0.719, p<0.001)$ te povećava udio varijance pogreške, a time i nepouzdanost takve kompozitne varijable.
Valjanost odabira ove mjere SSP sugeriraju i statistička svojstva raspodjele strojovođa s obzirom na tu mjeru: statistički odstupa od normalne raspodjele u smjeru pozitivne asimetrije u dvije od četiri promatrane dobne skupine na leksičkoj verziji, dok je u obojenoj verziji isto tako - što je očekivan smjer s obzirom da se radi o varijabli koja je predstavljena omjerom standardnih devijacija (i po tome je sličan F-omjeru koji se raspodjeljuje po pozitivno asimetričnoj raspodjeli).

Fluktuacije kod pojedinca ukazuju na prisutan varijabilitet koji je očekivan i ide u prilog sadržajnoj valjanosti. Raspodjele imaju nešto sužen varijabilitet koji nije homogen na svim dobnim skupinama kod leksičke verzije testa $\left(F=12.28, d f_{1}=\right.$ $\left.3, d f_{2}=46, p<0.001\right)$, ali jest kod obojene verzije testa $\left(F=1.00, d f_{1}=3, d f_{2}=48, p=.400\right)$.

Tablica 2. Deskriptivna statistika i rezultati Kolmogorov-Smirnov testa normaliteta za SSP

Table 2. Descriptive statistics and results of Kolmogorov-Smirnov normality test for SAS

\begin{tabular}{|c|c|c|c|c|c|c|c|c|}
\hline & $\begin{array}{c}\text { Dobne } \\
\text { skupine }\end{array}$ & $\mathbf{N}$ & $\mathbf{M}$ & SD & $\min -\max$ & $Z_{\text {skew }}$ & $K S_{z}$ & CV \\
\hline \multirow{4}{*}{$\begin{array}{c}\left(\mathrm{SD}_{\text {Stroop }} /\right. \\
\left.\mathrm{SD}_{\text {Bop }}\right)^{\prime} \\
\text { leksička }\end{array}$} & $20-29$ & 9 & 1.32 & 0.43 & $0.99-2.21$ & 1.87 & 0,885 & 32.24 \\
\hline & 30-39 & 13 & 1.08 & 0.11 & $0.90-1.33$ & 1.86 & 0.924 & 10.36 \\
\hline & $40-49$ & 17 & 1.09 & 0.13 & $0.96-1.47$ & $2.77^{* *}$ & 0.993 & 12.28 \\
\hline & 50-59 & 11 & 1.05 & 0.12 & $0.94-1.34$ & $2.23^{*}$ & 0.637 & 11.33 \\
\hline \multirow{4}{*}{$\begin{array}{c}\left(\mathrm{SD}_{\text {Stroop }} /\right. \\
\left.\mathrm{SD}_{\text {Bop }}\right) \\
\text { obojena }\end{array}$} & $20-29$ & 2 & 0.87 & 0.11 & $0.79-0.94$ & 1 & 1 & 12.45 \\
\hline & 30-39 & 23 & 1.08 & 0.23 & $0.93-2.06$ & $7.57^{* *}$ & $1.640^{* *}$ & 21.49 \\
\hline & $40-49$ & 17 & 1.06 & 0.08 & $0.97-1.24$ & $2.80^{* *}$ & 0.851 & 7.43 \\
\hline & 50-59 & 10 & 1.01 & 0.05 & 0.94-1.09 & -0.02 & 0,417 & 4.54 \\
\hline
\end{tabular}

${ }^{*} p<0.05 ;{ }^{* *} p<0.01$ 


\section{OSP}

OSP na djelovanje nepovoljnih čimbenika (zamor sustava, podložnost distraktorima, nepoželjne osobine ličnosti) izraženo je odnosom relativne pozicije prve omaške $u$ inkongruentnoj i neutralnoj komponenti Stroop-testa, te odnosom relativne pozicije prve pogreške $u$ inkongruentnoj i neutralnoj komponenti Stroop-testa. Što je prva omaška, ili prva pogreška u inkongruentnoj komponenti Stroop-testa više pomaknuta prema početku testa u odnosu na prvu omašku ili prvu pogrešku u neutralnoj komponenti Stroop-testa, to je sustav SP manje otporan na djelovanje nepovoljnih čimbenika. Za razliku od PESP i SSP, položaji prvih omaški u inkongruentnoj i neutralnoj komponenti leksičke verzije testa uopće nisu povezani $(r=0.071, p=0.625)$, dok su kod obojene verzije testa nisko povezani ( $r=0.379$, $p=0.006$ ), tako da oduzimanjem dviju varijabli ne dolazi do značajnog gubitka zdrave varijance, a time i značajne mogućnosti pada pouzdanosti kompozitne varijable. $U$ tom smislu, što je ova razlikovna (oduzimajuća) mjera otpornosti manja i teži negativnijim vrijednostima, OSP je manja.

U pogledu pogreški, povezanost položaja 1 . pogreške $\mathrm{u}$ inkongruentnoj i neutralnoj kompo- nenti testa nije se mogla pouzdano izračunati jer je broj pogrešaka bio vrlo malen (u leksičkoj inkongruentnoj verziji bilo ih je pet i u neutralnoj komponenti tri, dok se u obojenoj verziji u obje komponente javila samo jedna pogreška) te nije bilo potrebnog varijabiliteta za izračun korelacije. Iznimno mali varijabilitet broja pogreški razlog je za odustajanje od ove varijable kao indikatora OSP prema djelovanju nepovoljnih čimbenika.

Valjanost ovako dobivene mjere OSP na djelovanje nepovoljnih čimbenika očita je iz njezinih dominantno negativnih vrijednosti na većini dobnih skupina strojovođa, iz čega je razvidno da se 1. omaška u zahtjevnijoj, inkongruentnoj komponenti testa javlja ranije nego li u manje zahtjevnoj, neutralnoj komponenti testa. Valjanost sugeriraju i statistička svojstva raspodjele strojovođa s obzirom na tu mjeru: u gotovo svim dobnim skupinama strojovođa raspodjela statistički ne odstupa od normalne i jedina raspodjela koja odstupa nalazi se u najmlađoj dobnoj skupini leksičke verzije testa, gdje je odstupanje u smjeru negativne asimetrije proizveo jedan ekstremni rezultat. Raspodjele imaju iznimno velik varijabilitet koji je homogen na svim dobnim skupinama leksičke verzije testa $\left(F=2.149, d f_{1}=3, d f_{2}=46, p=0.107\right)$ i obojene verzije testa $\left(F=1.114, d f_{1}=3, d f_{2}=48, p=.353\right)$.

Tablica 3. Deskriptivna statistika i rezultati Kolmogorov-Smirnov testa normaliteta za OSP

Table 3. Descriptive statistics and results of Kolmogorov-Smirnov normality test for SAR

\begin{tabular}{|c|c|c|c|c|c|c|c|c|}
\hline & $\begin{array}{c}\text { Dobne } \\
\text { skupine }\end{array}$ & $\mathbf{N}$ & $\mathbf{M}$ & SD & $\min -\max$ & $Z_{\text {skew }}$ & $\boldsymbol{K} \boldsymbol{S}_{z}$ & CV \\
\hline \multirow{4}{*}{$\begin{array}{l}\text { (1.omaška } \\
\text { 1.omaškoop- } \\
\text { leksička }\end{array}$} & $20-29$ & 9 & -6.11 & 8.00 & $-26-1$ & $-3.15^{* *}$ & 0,887 & 131.02 \\
\hline & $30-39$ & 13 & -7.00 & 9.58 & $-18-8$ & 0.61 & 0.641 & 136.88 \\
\hline & $40-49$ & 17 & -1.88 & 7.07 & $-17-12$ & -0.36 & 0.496 & 374.74 \\
\hline & $50-59$ & 11 & 2.00 & 13.58 & $-20-24$ & 0.13 & 0.464 & 678.97 \\
\hline \multirow{4}{*}{$\begin{array}{l}\text { (1. omaška } \\
\text { Stroop- } \\
\text { 1. omaška } \\
\text { obop }) \\
\text { obojena }\end{array}$} & $20-29$ & 2 & 5 & 12.73 & $-4-14$ & / & / & 254.56 \\
\hline & 30-39 & 23 & -6.96 & 7.56 & $-18-11$ & 1.05 & 0.606 & 108.66 \\
\hline & $40-49$ & 17 & 1.58 & 10.03 & $-20-17$ & -0.71 & 0.705 & 631.63 \\
\hline & $50-59$ & 10 & -3.90 & 5.51 & $-14-7$ & 0.23 & 0.522 & 141.19 \\
\hline
\end{tabular}




\section{Međusobne korelacije PESP, SSP i OSP na djelovanje nepovoljnih utjecaja sustava $S P$}

O valjanosti odabranih mjera prosječne učinkovitosti, stabilnosti i otpornosti na djelovanje nepovoljnih utjecaja sustava $\mathrm{SP}$, mogu nešto reći i međusobne korelacije tih mjera: ako su one niske, to znači da te mjere ne procjenjuju iste konstrukte te da je bilo opravdano uzeti ih za mjerenje tri konstrukta dinamike funkcioniranja sustava SP kod hrvatskih strojovođa - (1) prosječne učinkovitosti, (2) stabilnosti, te (3) otpornosti na nepovoljne utjecaje sustava SP.

U leksičkoj verziji testa te korelacije jesu niske i većinom neznačajne ( $r_{\text {efikasnost - otpornost }}{ }^{-}-027$, $\left.p=0,852, r_{\boldsymbol{v}_{\text {(stabilnost }} * \text { otpornost) }}=-.001, p=0,993\right) \mathrm{s}$ time da jedina statistički značajna korelacija - između prosječne učinkovitosti i stabilnosti $(r=.398$, $p=0.005$ ) - i mora biti značajna jer prosječna učinkovitost u sebi jednim dijelom ipak uključuje stabilnost.

Također, u obojenoj verziji testa te korelacije su isto niske i većinom neznačajne $\left(r_{\text {efikasnost }}\right.$ otpornost ${ }^{\prime}=.064, p=0,651, r_{\left.\mho_{\text {(stabilnost }} * \text { otpornost }\right)}=-.080$, $p=0,574)$ s time da je opet jedina statistički značajna korelacija - između prosječne učinkovitosti i stabilnosti $(r=.334, p=0.015)$.

\section{Dobne razlike PESP, SSP i OSP pri djelovanju nepovoljnih čimbenika kod hrvatskih strojovođa}

Zbog djelomično nezadovoljenih pretpostavki dvosmjerne ANOVA-e, dobne razlike PESP, SSP i OSP u djelovanju nepovoljnih čimbenika nisu primarno ispitivane primjenom te analize na obje verzije testa istovremeno (leksičke i obojene), već su korištene zasebne jednosmjerne ANOVA-e za dvije verzije testa te njihove robusne inačice i neparametrijske analogije.

\section{Dobne razlike PESP}

Moguće dobne razlike u PESP na komparativan način sagledane su kod leksičke i obojene verzije testa selektivne pažnje.

U slučaju primjene leksičke verzije testa, premda postoji tendencija nelinearne dobne promjene PESP kod hrvatskih strojovođa (prvotni porast i zatim pad; vidi aritmetičke sredine Tablice 1.), ANOVA sugerira da ta tendencija nije statistički značajna $\left(F=1.89, d f_{1}=3, d f_{2}=46, p=0.145\right)$. Pri tome su pretpostavke za provedbu ANOVAe većinski zadovoljene: osim neprobabilističkog uzorka, može se reći kako broj ispitanika u pojedinim dobnim skupinama teži jednakim vrijednostima, rezultati unutar tih skupina su nezavisni i mjereni na omjernoj skali, raspodjele rezultata su normalne, te imaju homogene varijance (vidi deskriptivnu statistiku povezanu s Tablicom 1.).

U slučaju primjene obojene verzije testa, ponovno postoji tendencija nelinearne dobne promjene PESP kod hrvatskih strojovođa (prvo velik, a zatim sve manji pad; vidi aritmetičke sredine Tablice 1.). No, ona, sudeći po ANOVA-i, opet nije statistički značajna $\left(F=2.58, d f_{1}=3, d f_{2}=48, p=0.064\right)$. Pri tome pretpostavke za provedbu ANOVA-e u nešto većoj mjeri nisu zadovoljene: osim neprobabilističkog uzorka, postoje i značajne razlike u broju ispitanika pojedinih dobnih skupina, ali rezultati unutar tih skupina jesu nezavisni i mjereni na omjernoj skali, te su njihove raspodjele normalne i imaju homogene varijance (vidi deskriptivnu statistiku povezanu s Tablicom 1.).

S obzirom na manja odstupanja od pretpostavki ANOVA-e, a posebice zbog malih dobnih uzoraka, robusnim parametrijskim te neparametrijskim testovima provjerilo se i potvrdilo ANOVA-nalaze.

Tablica 4. Rezultati robusne ANOVA-e i neparametrije za dobne razlike u PESP

Table 4. Results of robust ANOVA and non-parametrics for age differences in SAAE

\begin{tabular}{|c|l|c|c|c|c||}
\hline Verzija testa & \multicolumn{1}{|c|}{ Analiza } & $\boldsymbol{F} / \boldsymbol{X}^{\mathbf{2}}$ & $\boldsymbol{d f _ { 1 }}$ & $\boldsymbol{d f _ { 2 }}$ & $\boldsymbol{p}$ \\
\hline \multirow{3}{*}{ Leksička } & Welch & 2.012 & 3 & 23.33 & 0.140 \\
\cline { 2 - 6 } & Brown-Forsythe & 1.951 & 3 & 39.84 & 0.137 \\
\cline { 2 - 6 } & Kruskal-Wallis & 4.88 & 3 & $/$ & 0.181 \\
\hline \hline \multirow{3}{*}{ Obojena } & Welch & 0.95 & 3 & 4.54 & 0.490 \\
\cline { 2 - 6 } & Brown-Forsythe & 1.58 & 3 & 3.80 & 0.331 \\
\cline { 2 - 6 } & Kruskal-Wallis & 4.05 & 3 & $/$ & 0.256 \\
\hline
\end{tabular}




\section{Dobne razlike SSP}

Moguće dobne razlike na sličan način sagledane su i kod SSP, za obje verzije testa - leksičku i obojenu.

Kod leksičke verzije testa vidljiv je trend nelinearnog smanjenja nestabilnosti (omjer SD) s dobi, odnosno povećanja stabilnosti sustava SP (oscilirajuće, ali dominantno povećanje SSP; vidi aritmetičke sredine Tablice 2.). Sama ANOVA sugerira značajno dobno povećanje stabilnosti $\left(F=3.40, d f_{1}=3, d f_{2}=46, p=0.025\right)$, ali taj nalaz treba sagledati u kontekstu zadovoljenosti pripadnih pretpostavki. Naime, razvidno je da postoji odstupanje od nekoliko pretpostavki za provedbu ANOVA-e, među kojima je neprobabilističko uzorkovanje, dijelom narušena normalnost distribucija te heterogenost varijanci (vidi deskriptivnu statistiku povezanu s Tablicom 2.). Zbog toga su provedeni robusni parametrijski te neparametrijski testovi, čiji rezultati nisu potvrdili značajnost dobnih razlika iz ANOVA-e (Tablica 5).

U obojenoj verziji testa postoji trend dominantno nelinearnog povećanja nestabilnosti, odnosno prevladavajućeg smanjenja stabilnosti sustava SP s dobi (prvotni veliki pad, a zatim vrlo blagi rast SSP; vidi aritmetičke sredine Tablice 2.). Ipak, ANOVA ne sugerira statistički značajne promjene $\left(F=1.30, d f_{1}=3, d f_{2}=48, p=0.286\right)$, ali zbog narušenosti njezinih pretpostavki - neprobabilističko uzorkovanje, nejednaka veličina dobnih skupina, pretežno odstupanje od normalnosti pripadnih raspodjela (vidi deskriptivnu statistiku povezanu s Tablicom 2.) - te zbog malih dobnih uzoraka, provedeno je robusno parametrijsko te neparametrijsko testiranje. Rezultati tih dodatnih testiranja potvrdili su ANOVA-nalaze o neznačajnim dobnim promjenama stabilnosti sustava SP kod hrvatskih strojovođa.

\section{Dobne razlike OSP}

Zbog navedenog premalenog varijabiliteta pogreški (koji ne osigurava pretpostavke za inferencijalne statističke postupke) dobne razlike u OSP testirane su samo kod operacionalizacije otpornosti putem omaški, dok su kod pogreški komentirane na razini deskriptivne statistike.

Kod leksičke verzije testa SP, u obje komponente testa pogreške se vrlo rijetko javljaju, a njihov raspored po komponentama i dobnim skupinama, kao i pozicija u testu, uglavnom su u skladu s očekivanjima:

- više je pogrešaka u inkongruentnoj $(n=5)$, nego u neutralnoj komponenti $(n=3)$;

- kod inkongruentne komponente najviše pogrešaka $(n=3)$ javlja se u dobi 30-39 godina te se uopće ne javlja u dobi 20-29, dok se kod neutralne komponente po jedna pogreška javlja u razdobljima 20-29, 40-49 i 50-59;

- kod neutralne komponente ta rijetka pogreška pomiče se ka ranijim zadacima (manja izdržljivost BOP-sustava starijih osoba), dok se kod inkongruentne komponente ta rijetka pogreška prvo pomiče ka ranijim zadacima, ali se u najstarijoj dobi naglo vraća na kasnije zadatke;

- pogreške kod inkongruentne komponente javljaju se osjetno ranije (prosječno kod 7. zadatka) nego kod neutralne komponente (prosječno između 16. i 17. zadatka).

Tablica 5. Rezultati robusne ANOVA-e i neparametrije za dobne razlike u SSP

Table 5. Results of robust ANOVA and non-parametrics for age differences in SAS

\begin{tabular}{||c|c|c|c|c|c||}
\hline \hline Verzija testa & Analiza & $\boldsymbol{F} / \boldsymbol{X}^{\mathbf{2}}$ & $\boldsymbol{d f}_{\boldsymbol{1}}$ & $\boldsymbol{d f _ { 2 }}$ & $\boldsymbol{p}$ \\
\hline \multirow{3}{*}{ Leksička } & Welch & 1.15 & 3 & 21.40 & 0.350 \\
\cline { 2 - 6 } & Brown-Forsythe & 2.49 & 3 & 11.72 & 0.111 \\
\cline { 2 - 6 } & Kruskal-Wallis & 2.69 & 3 & $/$ & 0.441 \\
\hline \multirow{3}{*}{ Obojena } & Welch & 2.31 & 3 & 4.79 & 0.198 \\
\cline { 2 - 6 } & Brown-Forsythe & 2.27 & 3 & 13.31 & 0.128 \\
\cline { 2 - 6 } & Kruskal-Wallis & 6.556 & 3 & $/$ & 0.087 \\
\hline
\end{tabular}


Kod obojene verzije testa SP u obje komponente testa javlja se samo po jedna pogreška, čiji raspored po dobnim skupinama i unutar testa uglavnom nije u skladu s očekivanjima:

- isti je broj pogrešaka u inkongruentnoj i neutralnoj komponenti $(n=1)$;

- kod obje komponente ta jedna pogreška javlja se u dobnoj skupini 30-39 godina;

- pogreška u inkongruentnoj komponenti javlja se kasnije (23. zadatak) nego li u neutralnoj komponenti (20. zadatak), premda je ta razlika vrlo mala.

Analize dobnih razlika otpornosti sustava SP putem relativnog odnosa pozicije prve omaške u nekongruentnoj i neutralnoj komponenti testa SP dale su konkretnije nalaze.

Kod leksičke verzije testa SP, premda postoji dobni trend dominantno nelinearnog smanjenja razlike u poziciji 1 . omaške $u$ inkongruentnoj $i$ neutralnoj komponenti testa (vidi aritmetičke sredine Tablice 3.) - odnosno, dobnog povećanja OSP - ANOVA sugerira da ono nije statistički značajno $\left(\mathrm{F}=2.09, d f_{1}=3, d f_{2}=46, p=0.114\right)$. Zapravo se pozicija 1. omaške u inkongruentnoj komponenti nije toliko mijenjala, ali se pozicija 1. omaške u neutralnoj komponenti pomicala prema početku testa. Određeno odstupanje od pretpostavki ANOVA-e (neprobabilističko uzorkovanje i manje odstupanje od ujednačenosti dobnih uzoraka) te mali dobni uzorci sugerirali su provjeru dobivenog rezultata robusnim parametrijskim te neparametrijskim postupcima, no njihova provedba samo je potvrdila dobiveni nalaz ANOVA-e (Tablica 6.).

Kod obojene verzije testa SP, uz neočekivane oscilacije u dobnim prosjecima (vidi aritmetič- ke sredine Tablice 3.), ipak razlike u poziciji 1. omaške inkongruentne i neutralne komponente testa pokazuju značajan dobni trend pada u dominantno negativne vrijednosti $\left(F=4.14, d f_{1}=3\right.$, $\left.d f_{2}=48, p=0.011\right)$. Premda bi se moglo zaključiti da dolazi do dobnog oscilirajućeg, ali postupnog smanjenja OSP, zapravo se dogodilo sljedeće: pozicija 1. omaške u inkongruentnoj komponenti nije se toliko mijenjala, ali se 1 . omaške u neutralnoj komponenti pomicao prema kraju testa ( $\mathrm{tj}$. BOP sustav sa starenjem je postajao sve otporniji na omaške). Takve dobne promjene uglavnom nisu u skladu s intuitivnim očekivanjima, a posebice ne jedina statistički značajna post-hoc razlika između dobne skupine 30-39 i 40-49 koja ukazuje na povećanje OSP između te dvije dobne skupine (Tablica 3.). Zbog odstupanja od probabilističkog uzorkovanja i nejednakih te malih dobnih uzoraka koji dovode u pitanje nalaze ANOVA-e, provedeni su neparametrijski Kruskal-Wallis test i parametrijski robusni testovi. Robusni testovi nisu dali rezultat u skladu $\mathrm{s}$ nalazima ANOVA-e, dok je neparametrijski test potvrdio značajni dobni trend pada relativne pozicije 1. omaške u inkongruentnoj i neutralnoj komponenti testa SP iz ANOVA-e (Tablica 6.).

\section{Ovisnost dobnih razlika PESP, SSP i OSP na djelovanje nepovoljnih čimbenika o prisutnosti prometno relevantnih boja}

Nalazi zasebnog testiranja dobnih promjena PESP, SSP i OSP nepovoljnim čimbenicima, za leksičku i obojenu verziju Stroop testa, sugeriraju da kod tih verzija testa SP rezultati samo dijelom ukazuju na isti ishod: dobne promjene PESP i SSP nisu značajne niti kod jedne verzije testa, ali pokazuju različite tendencije nelinearnih promjena za pojedinu verziju, dok se kod

Tablica 6. Rezultati robusne ANOVA-e i neparametrije za dobne razlike u OSP

Table 6. Results of robust ANOVA and non-parametrics for age differences in SAR

\begin{tabular}{||c|l|c|c|c|c||}
\hline Verzija testa & \multicolumn{1}{|c|}{ Analiza } & $\boldsymbol{F} / \boldsymbol{X}_{\mathbf{2}}$ & $\boldsymbol{d f _ { \boldsymbol { 1 } }}$ & $\boldsymbol{d f _ { \mathbf { 2 } }}$ & $\boldsymbol{p}$ \\
\hline \multirow{3}{*}{ Leksička } & Welch & 1.657 & 3 & 21.185 & .206 \\
\cline { 2 - 6 } & Brown-Forsythe & 1.932 & 3 & 30.491 & .145 \\
\cline { 2 - 6 } & Kruskal-Wallis & 5.257 & 3 & $/$ & .154 \\
\hline \multirow{3}{*}{ Obojena } & Welch & 2.54 & 3 & 4.65 & 0.178 \\
\cline { 2 - 6 } & Brown-Forsythe & 3.05 & 3 & 3.18 & 0.184 \\
\cline { 2 - 6 } & Kruskal-Wallis & 12.596 & 3 & $/$ & 0.006 \\
\hline
\end{tabular}


OSP konzistentno pokazalo kako se te dobne promjene razlikuju u leksičkoj i obojenoj verziji testa. Stoga, u odgovoru na pitanje jesu li dobne promjene tri razmatrana pokazatelja dinamike funkcioniranja SP ovisne o prisutnosti prometno relevantnih boja u mjerama tih konstrukata, svakako je najispravnije pokušati izravno odgovoriti na to pitanje dvosmjernom ANOVA-om, u kojoj su nezavisne varijable dobna skupina (NV1) i verzija testa selektivne pažnje (NV2). Značajan interakcijski učinak dobne skupine i verzije testa jasno bi sugerirao potvrđivanje 3. hipoteze.

No, pri tome je potrebna veća doza statističkog opreza nego li kod provedbe jednosmjerne ANOVA-e, s obzirom na to da je dvosmjerna ANOVA znatno osjetljivija na brojčanu nejednakost skupina definiranih razinama nezavisne varijable koje su $\mathrm{k}$ tome i osjetno manje (jer ih ima više) - zbog čega se mijenja i statistička značajnost pripadnih testova. Stoga i jesu prethodno provedene zasebne jednosmjerne ANOVA-e s pripadnim robusnim i neparametrijskim testovima koji, nažalost, ne postoje za dvosmjernu ANOVA-u, osim ako se ne primjenjuju samo kako bi provjerili nalaze glavnih učinaka.

Pretpostavke dvosmjerne ANOVA-e, koje su zadovoljene kod sva tri pokazatelja dinamike funkcioniranja SP, su omjerna skala rezultata i nezavisnost rezultata u pojedinim skupinama, dok nije zadovoljeno probabilističko uzorkovanje, brojčana jednakost uzorkovanih skupina, te dovoljna brojnost svih skupina.

Normalitet raspodjela tri pokazatelja u uzorkovanim skupinama zadovoljen je kod PESP (Tablica 1.) i OSP (Tablica 3.), a nije zadovoljen kod SSP (Tablica 2.).

Homogenost varijanci tri pokazatelja u uzorkovanim skupinama dvosmjerne ANOVA-e također je zadovoljena kod PESP $\left(F=1.402, d f_{1}=\right.$ $\left.7, d f_{2}=94, p=.214\right)$ i OSP $\left(F=1.547, d f_{1}=7\right.$, $\left.d f_{2}=94, p=0.161\right)$, a nije zadovoljena kod SSP $\left(F=5.480, d f_{1}=7, d f_{2}=94, p=<0.001\right)$.

Činjenica da su kod dva od tri pokazatelja dinamike funkcioniranja SP pretpostavke za dvosmjernu ANOVA-u većinom zadovoljene suge- rira kako je potrebno provesti i interpretirati tri zasebne analize.

\section{PESP u ovisnosti o dobi i vrsti SP testa}

Rezultati dvosmjerne ANOVA-e pokazuju da interakcijski učinak dobne skupine i vrste testa jest značajan $\left(F=3.514, d f_{1}=3, d f_{2}=94, p=0.018\right)$, odnosno da se dobne promjene u PESP razlikuju ovisno o tome sadrži li test SP prometno relevantne boje, ili ne. Naime, kad test sadrži relevantne boje, tada PESP pokazuje sustavan, ali neznačajan trend pada s dobi (s najvećim padom između najmlađih dobnih skupina). Kad test ne sadrži relevantne boje, tada PESP pokazuje neznačajan trend prvotnog rasta, zatim stagnacije te potom pada.

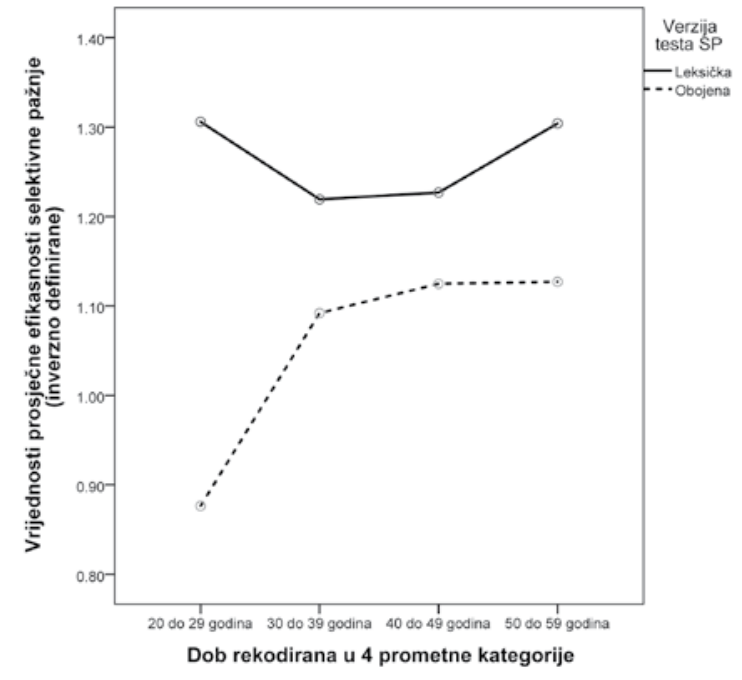

Grafikon 1. Ovisnost PESP hrvatskih strojovođa o dobnoj skupini i verziji testa $S P$

Figure 1. Relation of $S A A E$ in Croatian drivers to age group and $S A$ test version

Kao sekundarni nalaz ove analize može se navesti glavni učinak dobne skupine, te ga komentirati zajedno s analizama 2. hipoteze istraživanja. Taj učinak nije se pokazao statistički značajnim $\left(F=2.074, d f_{1}=3, d f_{2}=94, p=0.109\right)$ premda postoji trend dominantnog pada PESP $\mathrm{s}$ dobi neovisno o verziji testa.

Glavni učinak dobi provjeravan neparametrijskim Kruskal-Wallis testom ipak se pokazao granično značajnim $\left(\chi^{2}=8.224, d f=3, p=0.042\right)$, a pored trenda dominantnog pada PESP (posebice 
od 30-39 do 50-59 godina) vidljiv je značajan prosječni porast tog pokazatelja SP između dvije najmlađe dobne skupine (Tablica 7.).

Kao tercijarni nalaz ove analize može se navesti evidentan glavni učinak verzije testa SP $\left(F=45.495, d f_{1}=1, d f_{2}=94, p<0.001\right)$ koji govori da je PESP veća (odnosno, interferencija manja) kod obojenih zadataka SP, nego kod leksičkih zadataka. To je zanimljiv podatak koji, prvenstveno iz metodoloških razloga, nije uvršten u hipoteze istraživanja (više u Raspravi). Zbog dijela narušenih pretpostavki dvosmjerne ANOVA-e, ovaj glavni učinak provjeren je i potvrđen t-testom $(t=6.208, d f=100, p<0.001)$, te neparametrijskim Mann-Whitney testom (M-W $U=500.5, z=-5.345, p<0.001)$.

\section{SSP u ovisnosti o dobi i vrsti SP testa}

Rezultati dvosmjerne ANOVA-e pokazuju da interakcijski učinak dobne skupine i vrste testa jest granično značajan $\left(F=2.787, d f_{1}=3, d f_{2}=94\right.$, $p=0.045)$, odnosno da se dobne promjene u SSP razlikuju ovisno o tome sadrži li test SP prometno relevantne boje ili ne. Kad test sadrži prometno relevantne boje, tada stabilnost pokazuje neznačajan trend prvotnog pada (između 20-29 i 30-39), a potom njezine stagnacije ili čak blagog rasta $\mathrm{s}$ dobi. S druge strane, kad test ne sadrži relevantne boje, tada stabilnost pokazuje neznačajan trend prvotnog rasta, a zatim stagnacije.

Sekundarni nalaz ove analize - glavni učinak dobne skupine - može se komentirati zajedno s analizama 2. hipoteze istraživanja. Taj učinak nije se pokazao statistički značajnim ( $F=0.334$, $\left.d f_{1}=3, d f_{2}=94, p=0.800\right)$, premda postoji trend sustavnog rasta SSP s dobi, neovisno o verziji testa. Neparametrijska provjera (Kruskal-Wallis testom) ovog učinka potvrdila je neznačajan učinak dobi $\left(\chi^{2}=2.580, d f=3, p=0.461\right)$.

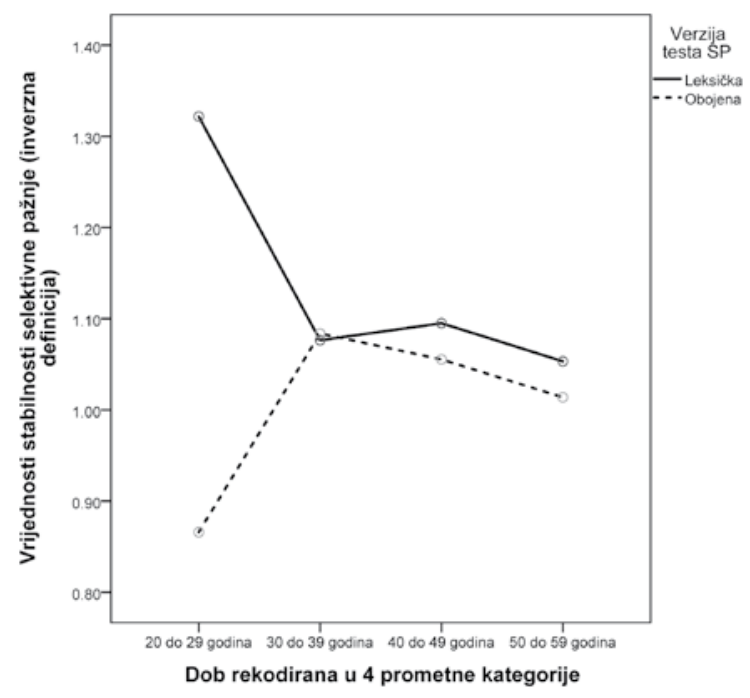

Grafikon 2. Ovisnost SSP hrvatskih strojovođa o dobnoj skupini i verziji testa $S P$

Figure 2. Relation of SAS in Croatian drivers to age group and $S A$ test version

Kao tercijarni nalaz ove analize ponovno se može navesti evidentan glavni učinak verzije testa SP $\left(F=7.499, d f_{1}=1, d f_{2}=94, p=0.007\right)$, koji govori da je SSP znatno veća u testu koji sadrži prometno relevantne boje nego li u testu koji ne sadrži relevantne boje. Zbog većinski narušenih pretpostavki dvosmjerne ANOVA-e, ovaj glavni učinak provjeren je t-testom $(t=1.755, d f=90.41$, $p=0.083)$, te neparametrijskim Mann-Whitney testom (M-W $\quad U=1068.0, \quad z=-1.553, p=0.120)$ koji ipak nisu potvrdili tendenciju da strojovođe budu stabilniji u obojenoj verziji testa.

\section{Tablica 7. Prosječni rangovi PESP pripadni pojedinim dobnim skupinama hrvatskih strojovođa}

Table 7. Average SAAE ranking for Croatian drivers of different age groups

\begin{tabular}{|c|c|c|}
\hline Dob rekodirana u 4 prometne kategorije & $\mathbf{N}$ & Prosječni rang \\
\hline 20 do 29 godina & 11 & 64,50 \\
\hline 30 do 39 godina & 36 & 42,17 \\
\hline 40 do 49 godina & 34 & 50,87 \\
\hline 50 do 59 godina & 21 & 61,71 \\
\hline ukupno & 102 & \\
\hline
\end{tabular}




\section{OSP u ovisnosti o dobi i vrsti SP testa}

Rezultati dvosmjerne ANOVA-e pokazuju da interakcijski učinak dobne skupine i vrste testa na OSP nije značajan $\left(F=1.984, d f_{1}=3, d f_{2}=94\right.$, $p=0.122)$, odnosno da su dobne promjene OSP statistički jednake za test SP koji sadrži i koji ne sadrži prometno relevantne boje. Obje verzije testa ukazuju na pad s 20-29 na 30-39 godina, a potom rast sa 30-39 na 40-49 godina, pri čemu su ove oscilacije izraženije u testu s prometno relevantnim bojama.

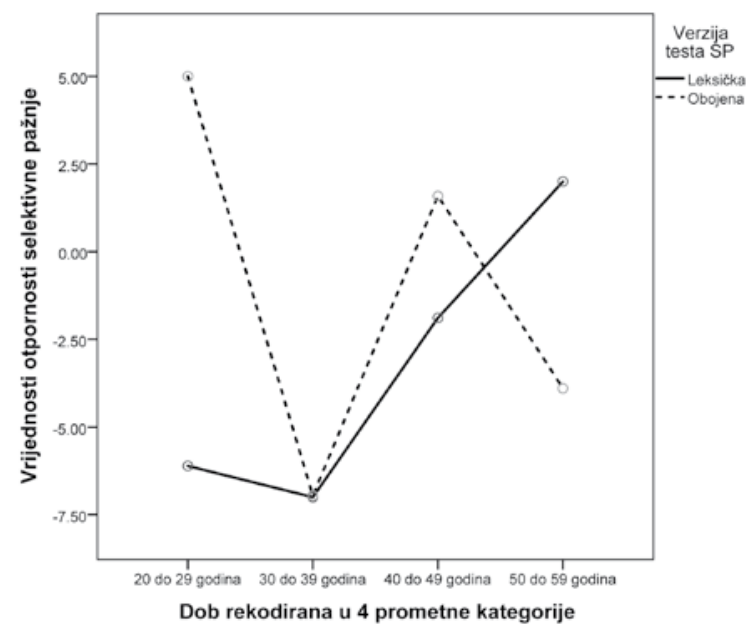

Grafikon 3. Ovisnost OSP hrvatskih strojovođa o dobnoj skupini i verziji testa

Figure 3. Relation of SAR in Croatian drivers to age group and test version

Glavni učinak dobne skupine, kao sekundarni nalaz ove analize (koji se može komentirati zajedno s analizama 2. hipoteze istraživanja), pokazao se statistički značajnim ( $F=3.744$, $\left.d f_{1}=3, d f_{2}=94, p=0.014\right)$ neovisno o verziji testa.
Potvrđen je i neparametrijskim Kruskal-Wallis testom $\left(\chi^{2}=13.205, d f=3, p=0.004\right)$, a odražava prvenstveno spomenuti porast otpornosti sa 3039 na 40-49 godina (Tablica 8.).

Konačno, kao tercijarni nalaz ove analize može se navesti neznačajan glavni učinak verzije testa SP $\left(F=0.913, d f_{1}=1, d f_{2}=94, p=0.342\right)$ koji govori da ne postoji značajna razlika u otpornosti sustava SP između dvije verzije testa, a neovisno o dobi. Ipak, strojovođe pokazuju nešto veću OSP $\mathrm{u}$ testu s prometno relevantnim bojama pa se, zbog djelomično narušenih pretpostavki dvosmjerne ANOVA-e, ovaj glavni učinak provjerio te ponovno odbacio t-testom $(t=0.051, d t=100$, $p=0.960)$ i neparametrijskim Mann-Whitney testom (M-W $U=1266.5, z=-0.225, p=0.822)$.

\section{RASPRAVA}

\section{Teorijska i empirijska valjanost tri novouvedena pokazatelja dinamike funkcioniranja sustava SP u populaciji hrvatskih strojovođa}

Prosječna učinkovitost svakog kognitivnog procesa (ili pripadnog kognitivnog podsustava), aktiviranog tijekom rješavanja nekog kognitivnog zadatka, redovito se izražava mjerom centralne tendencije (aritmetička sredina ili medijan) pojedinčevih uradaka u svim zadacima pripadnog kognitivnog testa (Drenovac, 2009., Jensen, 2006., Žebec et al., 2014.). Prosječna učinkovitost inhibitornog sustava SP u provedenom istraživanju nije mjerena razlikom između prosječne latencije točnog odgovora i/ili broja netočnih odgovora u inkongruentnoj i neutralnoj komponenti Stroop testa - kao što je to najčešće

Tablica 8. Prosječni rangovi OSP pripadni pojedinim dobnim skupinama hrvatskih strojovođa

Table 8. Average SAR ranking for Croatian drivers of different age groups

\begin{tabular}{|l|c|c||}
\hline Dob rekodirana u 4 prometne kategorije & N & Prosječni rang \\
\hline 20 do 29 godina & 11 & 48.64 \\
\hline 30 do 39 godina & 35 & 37.90 \\
\hline 40 do 49 godina & 35 & 62.56 \\
\hline 50 do 59 godina & 21 & 57.24 \\
\hline ukupno & 102 & \\
\hline
\end{tabular}


slučaj u literaturi (MacLeod, 1991., Ludwig et al., 2010.) - već je izražena omjerom prosječne latencije točnog odgovora (60s/ukupan broj točno precrtanih ciljnih riječi) u inkongruentnoj i neutralnoj komponenti testa, a netočni odgovori analizirani su kao zaseban pokazatelj dinamike funkcioniranja SP. Razlog novoj operacionalizaciji PESP jest u velikom udjelu varijance pogreške kod razlike dviju, međusobno visoko povezanih prosječnih latencija točnog odgovora (inkongruentnoj i neutralnoj); (Žebec et al., 2016.), a koja se većinom izbjegava omjerom tih dviju varijabli. Omjerna operacionalizacija PESP, premda je izvedena iz prosječne latencije odgovora, više nema smisao vremenske mjere interferencije, ali je s njom vrlo visoko povezana te i dalje predstavlja inverznu mjeru SP (što je omjer veći, to je pojedincu trebalo više vremena da u uvjetima interferencije odgovori na zadatak, a u odnosu na uvjete bez interferencije, te je stoga njegova SP slabija). Definiranje dinamike kognitivnih procesa putem omjera latencije odgovora prisutno je u prethodnim istraživanjima, ali su korištene latencije rješavanja različitih dijelova istog testa i u skladu s time analizirani drugi pokazatelji dinamike (Drenovac, 2009.). Zbog svega navedenog može se zaključiti kako je omjerna operacionalizacija PESP teorijski valjana, s time da visoka povezanost s klasičnom (razlikovnom) mjerom PESP već dijelom ukazuje i na empirijsku potvrdu te valjanosti. Druge empirijske potvrde valjanosti ovako definirane PESP na uzorku hrvatskih strojovođa proizlaze iz: (1) očekivanih vrijednosti PESP većih od 1 , u obje verzije testa (iz čega je očito da je prosječno vrijeme odgovora dulje u inkogruentnim uvjetima); (2) nešto smanjene, ali zadovoljavajuće i dobno stabilne diskriminativnosti PESP pokazatelja koja je nešto veća u obojenoj verziji Stroop testa; te iz (3) uglavnom očekivanog, premda neznačajnog trenda starosnog pada SP.

Stabilnost nekog kognitivnog procesa (ili rada pripadnog kognitivnog podsustava), aktiviranog tijekom rješavanja danog kognitivnog zadatka, najčešće se izražava mjerom varijabiliteta (posebice standardnom devijacijom) pojedinčevih uradaka u svim zadacima pripadnog kognitivnog testa (Drenovac, 2009., Jensen, 2006., Myerson et al., 2007.), pa je stoga SSP definiran omjerom standardne devijacije broja točno precrta- nih ciljnih riječi u inkongruentnoj i standardne devijacije broja istih riječi u neutralnoj komponenti Stroop testa. Omjerna operacionalizacija SSP ponovno je posljedica nastojanja da se izolira nestabilnost inhibitornog sustava SP u inkongruentnim podražajnim uvjetima (a u odnosu na nestabilnost kognitivnog funkcioniranja u neutralnim podražajnim uvjetima), te relativno visoke korelacije među dvjema standardnim devijacijama iz omjera (čije bi oduzimanje dalo visoko nepouzdanu mjeru nestabilnosti isključivo zbog neinhibirane interferencije). Omjerna operacionalizacija SSP, premda nije toliko izravna mjera nestabilnosti proizvedene inkongruentnim uvjetima kao razlikovna operacionalizacija, i dalje predstavlja inverznu mjeru SSP (što je omjer veći, to je pojedinčevo odgovaranje bilo nestabilnije uvjetima interferencije, a u odnosu na uvjete bez interferencije, pa je stoga njegova SSP veća) te je teorijski jednako vrijedna kao i PESP. Empirijske potvrde valjanosti SSP na uzorku hrvatskih strojovođa povezane su s: (1) teorijski očekivane vrijednosti SSP veće od 1, u obje verzije testa (iz čega je razvidno da je nestabilnost odgovaranja veća u inkogruentnim uvjetima); te (2) nešto smanjene, ali zadovoljavajuće diskriminativnosti SSP promatranih dobnih skupina koje su veće u leksičkoj verziji Stroop testa. Nejasan i statistički neznačajan trend dobnih promjena na prvi pogled nije u skladu s očekivanjima te ne govori u prilog empirijskoj valjanosti SSP. Zbog zdravstvene specifičnosti populacije strojovođa, nepostojanja ispitanika starijih od 59 godina te niskih kognitivnih zahtjeva inkongruentnog uvjeta (West et al., 2002.), pitanje je mogu li se uopće očekivati ikakve dobne promjene SSP-a.

Otpornost kognitivnog sustava djelovanju nepovoljnih čimbenika tijekom njegove aktivnosti (tj. podložnost distraktorima, zamor sustava duljim trajanjem kognitivne aktivnosti, djelovanje nepovoljnih osobina ličnosti u širem smislu) je konstrukt koji je u testovima brzine najčešće povezan s obilježjima pripadnih kognitivnih procesa kao što su točnost ili pouzdanost (Drenovac, 2009., Jensen, 2006.), zamorljivost ili izdržljivost (Drenovac, 2009., Žebec, 2004.), najgora izvedba, ili slabost kognitivnog sustava (Coyle, 2003., Žebec et al., 2014.), te funkcionalne blokade (Drenovac, 2009.). Taj pokazatelj dinamike kognitivnog funkcioniranja moguće je izraziti 
brojem netočnih odgovora, ili trajanjem najlošijeg/najduljeg odgovora. No, u ovome radu, zbog vrlo malog broja netočnih odgovora i metodologije koja nije omogućila mjerenje pojedinačnog vremena precrtavanja ciljne riječi (a samim time i određivanja najduljeg odgovora) izražen je relativnom pozicijom prvog netočnog odgovora u inkongruentnoj i neutralnoj komponenti Stroop testa. Dodatno, kako su netočni odgovori podijeljeni u pogreške i omaške (Sternberg, 2005.), a pogreške su bile iznimno rijetke, kao jedini razmatrani pokazatelj OSP ostala je relativna pozicija prve omaške u inkongruentnoj i neutralnoj komponenti Stroop testa. Razlika između položaja prve omaške u inkongruentnoj i neutralnoj komponenti Stroop testa korištena je kao operacionalizacija OSP jer su ta dva položaja nisko (ako uopće) korelirana pa toj razlikovnoj operacionalizaciji nije ugrožena pouzdanost. $\mathrm{Na}$ osnovi navedenog očita je dobra teorijska valjanost OSP-pokazatelja koja je empirijski potvrđena očekivanim, dominantno negativnim vrijednostima (jer se omaške ranije javljaju u zahtjevnijim zadacima inkongruentne komponente), a koje su nešto manje izražene u obojenoj formi Stroop testa. Empirijske potvrde valjanosti OSP na uzorku hrvatskih strojovođa mogu se prepoznati u visokoj te ujednačenoj diskriminativnosti te mjere na svim promatranim dobnim skupinama. S druge strane, dobne promjene ove mjere OSP nisu jednoznačne kod leksičke i obojene verzije testa i uglavnom odražavaju samo dobnu promjenu položaja prve omaške u neutralnoj komponenti Stroop testa, te se (uz ogradu zbog narušenosti pretpostavki korištenih statističkih analiza tih promjena) ne mogu koristiti kao argument empirijske valjanosti (posebice jer niski kognitivni zahtjevi inkongruentnih uvjeta, zdravstvena specifičnost strojovođa i najstariji uzrast od svega 59 godina, dovode u pitanje ikakve dobne razlike).

\section{Učinci starenja na PESP, SSP i OSP neovisni o vrsti testa SP}

Testiranje dobnih razlika PESP, definirane na novi način (omjerom, a ne razlikom prosječnih latencija točnog odgovora $u$ inkongruentnoj $i$ neutralnoj komponenti testa), zasebno za svaku verziju Stroop testa, ne ukazuje na postojanje značajnog nelinearnog smanjenja PESP u pro- matranom dobnom rasponu, kako u leksičkoj, tako i u obojenoj verziji testa - premda je ta tendencija postojala kod obje verzije testa. No, kada je u sklopu dvosmjerne ANOVA-e, zbog njezinih narušenih pretpostavki, glavni učinak dobi testiran neparametrijskim Kruskal-Wallis testom, dobno smanjenje PESP pokazalo se granično značajnim. Pri tome se najveća promjena tog pokazatelja SP - sa smjerom suprotnim konvencionalnim očekivanjima (povećanje PESP) očitovala između dvije najmlađe dobne skupine, ali kasnije (od 30-39 do 50-59 godina) dominira očekivani trend pada PESP. Takvi nalazi, na prvi pogled, nisu u skladu s očekivanjima temeljenim na istraživanjima koja govore o većoj uspješnosti mlađih u odnosu na starije sudionike u zadacima SP (Hartley, 1993., Mutter et al., 2005., Ben-David i Schneider, 2009., Davidson et al., 2003., McGaughy i Eichenbaum, 2002.). No, postoje razlozi zašto i ne trebaju biti. Prvo, spomenuta istraživanja dominantno su ispitivala razlike u PESP između dvije dobne skupine (prosječne dobi 25 i 65 godina), pri čemu starija dobna skupina redovito prelazi granicu od 60 godina, iznad koje se događa najveća deterioracija sustava SP (Ardila, 2007., Salthouse i Davis, 2006., Salthouse et al., 2008; Span et al., 2004. $)^{3}$ - a te dobi nisu uključene u istraživanje jer strojovođe nakon navršene 60 . godine redovito odlaze u mirovinu. Drugo, ispitivana populacija strojovođa bar je donekle zdravstveno selekcionirana i stalno nadzirana (Pravilnik o ovlaštenju strojovođa), tako da, ako deterioracijske promjene i postoje, one bi trebale biti manje izražene nego li kod prosječne populacije (iz navedenih istraživanja), unatoč činjenici da radni uvjeti profesionalnih vozača štetno djeluju na njihovo zdravlje te mogu započeti i ranije (Backman, 1983., Taylor i Dorn, 2006.). No, ovo objašnjenje ne može se uzeti kao relevantno sve dok se ne provede identičan istraživački nacrt na kontrolnoj skupini odraslih muških osoba komparabilnih sociodemografskih osobina, ali zanimanja drugačijih od strojovođa. Treće, korištene

\footnotetext{
${ }^{3}$ Nema specifičnih podataka o veličini deterioracije SP nakon dobi od 60 godina. No, prethodna istraživanja (Brink i McDowd, 1999. Ludwig et al., 2010., Madden i Langley, 2003.) sugeriraju da se značajna kognitivna deterioracija može registrirati samo kada se uspoređuju mlađe osobe s onima starijima od 60 ili 65 godina (iako to ovisi ponajviše o verziji Stroop testa); (Brink i McDowd, 1999., Ludwig et al., 2010).
} 
su drugačije operacionalizacije PESP (i na razini podražajnog materijala, ali i na razini kompozitne mjere PESP), pri čemu je upitno je li naša operacionalizacija sadržavala niže inhibicijske zahtjeve u inkongruentnoj komponenti Stroop testa od onih u prethodnim istraživanjima. Konačno, dodatno razmatranje dobnih promjena prosječnih latencija točnog odgovora u inkongruentnoj i neutralnoj komponenti Stroop testa, pokazuju uglavnom nelinearan porast prosječne latencije točnog odgovora sa starenjem - što je potpuno očekivan nalaz - koji je kod obojene verzije testa značajan (F-inkongruentno $=7.174$, $d f_{1}=3, d f_{2}=48, p<0.001 ; \quad F-n e u t r a l n o=5.059$, $\left.d f_{1}=3, d f_{2}=48, p<0.01\right)$, dok kod leksičke nije (Finkongruentno $=1.474, d f_{1}=3, d f_{2}=46, p>0.05$; F-neutralno $\left.=0.677, d f_{1}=3, d f_{2}=47, p>0.05\right)$. Dakle, starosni porast prosječne latencije točnog odgovora u inkongruentnoj komponenti, premda postoji, nije dovoljno velik u odnosu na onaj u neutralnoj komponenti, da bi se pad PESP pokazao značajnim (štoviše, pokazalo se da veći porasti prosječnih latencija u obojenoj verziji daju manji porast omjera tih latencija, nego li kod leksičke verzije). Potencijalno pojašnjenje za nešto manju PESP kod najmlađe skupine (20-29) u odnosu na iduću (30-39) može biti u mladenačkoj impulzivnosti, koja je negativno povezana s inhibicijskim mehanizmima, ali i imati metodološku pozadinu: najmlađa skupina je i znatno manje brojna od ostalih dobnih skupina (što je posebno istaknuto u obojenoj verziji testa) pa rezultate treba promatrati s obzirom na pristranost uzorka. Općenito, veličina uzorka na kojem je primijenjen svaki od Stroop testova nije zavidna (premda ispitani strojovođe predstavljaju zamjetan postotak cijele RH-populacije strojovođa), zbog čega statističke analize nemaju veliku statističku snagu te zbog čega se niti učinak dobi nije mogao lako očitovati. Dodatno, korisno je istaknuti da se nikakve dobne promjene u obojenoj verziji te jedva značajne promjene u leksičkoj verziji dobivaju kada se iste analize provedu na istim ovim podacima, samo s drugačijom definicijom PESP - razlikovnom, a ne omjernom (Žebec et al., 2016.).

Mogući učinak starenja na SSP još je konzistentnije odbačen nego li kod PESP jer se glavni učinak dobi u dvosmjernoj ANOVA-i - s pripadnim Kruskal-Wallis testom - nije pokazao zna- čajnim, a od dvije zasebne jednosmjerne ANOVA-e $s$ pripadnim robusnim i neparametrijskim testovima, samo se jedna ANOVA (premda $s$ narušenim pretpostavkama) pokazala statistički značajnom. Štoviše, neznačajne tendencije dobnih promjena SSP, koje se mogu primijetiti, suprotnog su smjera kod dvije verzije Stroop testa - dobno povećanje SSP kod leksičke, a dobno smanjenje SSP kod obojene verzije testa. S druge strane, promatranje dobnih učinaka na SSP obje verzije testa zajedno (glavni učinak dvosmjerne ANOVA-e i pripadni neparametrijski test) ukazalo je na neznačajnu tendenciju neočekivanog prosječnog dobnog povećanja SSP i time potvrdilo nejednoznačnost starosnih promjena SSP. Nepostojanje jednoznačne, statistički značajne linearne, ili nelinearne - starosne promjene SSP, odražava i složenost njezine omjerne operacionalizacije (koja implicira drugačiji rast SD rezultata inkongruentne komponente, a u odnosu na SD rezultata neutralne komponente Stroop testa) jer komponente ove omjerne operacionalizacije zapravo pokazuju teorijski očekivan trend. Naime, dodatne analize SD rezultata inkongruentne i neutralne komponente testa pokazale su trend očekivanog dominantno nelinearnog porasta $s$ dobi, koji je bio nešto više izražen kod obojene verzije, te se kod inkongruentne komponente pokazao statistički značajnim (F-inkongruentno= 4.620, $\left.d f_{1}=3, d f_{2}=48, p<0.01\right)$. Navedene nalaze teško je interpretirati zbog nekih metodoloških ograničenja kao što su: (1) mala statistička snaga zbog male veličine uzorka - posebice najmlađe skupine, čiji rezultati su time manje pouzdani; (2) eventualno nedostatna količina interferencije $\mathrm{u}$ inkongruentnom uvjetu, u odnosu na neutralni uvjet Stroop testa; te (3) smanjena osjetljivost SD rezultata, $\mathrm{tj}$. binarnih odgovora svake komponente Stroop testa, a zbog velike točnosti rješavanja testova brzine. No, ove nalaze nije lako interpretirati, kako zbog spomenute nedostupnosti ispitivanja kontrolne skupine muškaraca iz populacije "ne-strojovođa", tako i zbog nedostatka komparabilnih istraživanja. Naime, jedno od rijetkih dostupnih istraživanja koja se bave pojedinčevim (intraindividualnim) fluktuacijama, ili nestabilnošću funkcioniranja sustava pažnje zbog starenja, je istraživanje West i suradnika (2002.). No, ono nije usmjereno samo na selektivnu pažnju (bavi se širim konstruktom izvršne kontrole) i zbog toga koristi drugačiju 
mjeru funkcioniranja pažnje (zadaci neposrednog i odgođenog kratkoročnog pamćenja u uvjetima distrakcije), ali i različiti dobni uzorak (dvije dobne skupine: mlađu, s prosjekom 23,9 godina i stariju, s prosjekom 73,8 godina) te različitu populaciju (opću, a ne selekcioniranu populaciju strojovođa). Nalazi tog istraživanja ukazuju na veći intraindividualni varijabilitet izvršne kontrole u starijoj dobi, ali samo kod zadatka s većim zahtjevima na izvršnu kontrolu. S obzirom da je zadatak odgođenog kratkoročnog pamćenja u uvjetima distrakcije osjetno zahtjevniji od Stroop zadatka ovog istraživanja, nalazi SSP ovog istraživanja zapravo su u skladu s istraživanjem Westa i suradnika (2002.). Druga dostupna istraživanja koja se bave dobnim promjenama intraindividualnog varijabiliteta - ali ne SP, već kognitivnog funkcioniranja $u$ jednostavnijim zadacima vremena reakcije (BOP) - ukazuju na veći intraindividualni varijabilitet u starijoj dobi (Adelman et al., 2016., MacDonald et al., 2003., Myerson et al., 2007.). No, pripadni nalazi mogu se samo u ograničenoj mjeri koristiti za evaluaciju učinaka starenja SSP u ovom istraživanju, kako zbog različitih kognitivnih mjera, tako i zbog bitno drugačijeg uzorka - i u pogledu ciljne populacije, ali i u pogledu starijih dobnih skupina koje redovito uključuju dob iznad 60 godina.

Premda je broj netočnih odgovora inače korisna mjera interferencije (Jensen i Rohwer, 1966., West i Alain, 2000., MacLeod, 1998.), ona u ovom istraživanju nije pokazala psihometrijska svojstva nužna za njihovo uključenje u statističko testiranje postavljenih hipoteza (vrlo mali broj i vrlo mali varijabilitet broja pogrešaka i omaški). $\mathrm{S}$ druge strane, relativna pozicija prve omaške inkongruentne komponente testa u odnosu na neutralnu, bila je psihometrijski pogodna za testiranje hipoteza u vezi s OSP, ali su njezinim korištenjem dobiveni nalazi koje nije jednostavno protumačiti. Naime, u obje verzije Stroop testa očekivalo se postupno smanjenje OSP na djelovanje nepovoljnih čimbenika zbog starosne deterioracije sustava SP (Mutter et al., 2005., Ben-David i Schneider, 2009., Davidson et al., 2003., McGaughy i Eichenbaum, 2002.), a rezultati to nisu potvrdili. Prvo, glavni učinci dobi u dvosmjernoj ANOVA-i pokazali su se značajnim, kao i pripadni neparametrijski Kruskal-Wallis test, s dominantnim dobnim porastom prosječnih rangova. Drugo, nalazi jednosmjerne ANOVA-e nisu potvrdili statističku značajnost starosnog pada u leksičkoj verziji testa (štoviše, postojao je suprotan trend starosnog rasta OSP), dok je u obojenoj verziji testa dobiven dvoznačan nalaz: uz određene dobne oscilacije, zabilježen je statistički značajan i prevladavajući pad OSP s dobi, premda je jedina značajna post-hoc razlika (između skupina 30-39 i 40-49) ukazivala na porast OSP. K tome, kod obje verzije testa dobivene tendencije starosnih promjena OSP primarno su posljedica pomicanja pozicije prve omaške u neutralnoj komponenti Stroop testa, dok je pozicija prve omaške inkongruentne komponente Stroop testa dobno relativno stabilna. Pored mogućih metodoloških obrazloženja u vezi s pretpostavkama ANOVA-e, dodatni razlozi ovakvim dobnim promjenama OSP mogu se tražiti u specifičnom uzorku strojovođa koji ne prelazi deterioracijsku granicu od 60 godina te obuhvaća zdravstveno pozitivno selekcionirane pojedince (premda izložene dodatnim profesionalnim izvorima deterioracije, poput smjenskog rada). Ta specifičnost populacije profesionalnih vozača vidljiva je i u istraživanju Drenovca i Drenovca (1989a) prema čijim nalazima profesionalni vozači, bez obzira na dob, pokazuju veću stabilnost, brzinu i točnost prilikom rješavanja zadatka kompleksnog psihomotornog reagiranja na Complex Reactionmeter Drenovac (CRD), a u odnosu na vozače osuđene zbog izazivanja sudara. Još jedan relevantan čimbenik koji nije sustavno kontroliran u nacrtu istraživanja, a koji je eventualno doveo do odstupanja starosnih promjena OSP od očekivanog pada jesu i posljedice smjenskog rada, za koje se pretpostavilo da su pravilno raspoređene po dobnim skupinama hrvatskih strojovođa, premda za to nije bilo jamstva. Primjerice, u istraživanju učinka dispečera (Drenovac i Drenovac, 1989b) u rješavanju mentalnih i psihomotornih zadataka koji su uključivali zadatke vizualne orijentacije, operativnog pamćenja i mišljenja (ispitivanih pomoću CRD-a), autori su kod ukupne razine učinka i brzine rješavanja, te točnosti i stabilnost pronašli izrazita kolebanja tijekom smjene, ali ipak s nešto nižom statističkom značajnosti kod točnosti i stabilnosti.

\section{Ovisnost starosnih promjena PESP, SSP i OSP o vrsti testa SP}

Dobne razlike u PESP ne pokazuju isti obrazac za PESP-mjeru koja sadrži prometno relevantne 
boje (obojena verzija Stroop testa), kao i za onu koja te boje ne sadrži (leksička verzija Stroop testa): (1) kad test sadrži relevantne boje, PESP pokazuje sustavan, ali neznačajan trend pada $\mathrm{s}$ dobi (najviše izražen između najmlađih dobnih skupina), a (2) kad ne sadrži relevantne boje, PESP pokazuje neznačajan trend prvotnog rasta, zatim stagnacije te potom pada. Sličan, ali nešto manje izražen interakcijski učinak starenja i vrste Stroop testa značajan je i kod SSP: (1) kad test sadrži prometno relevantne boje, SSP pokazuje osjetan, ali neznačajan trend prvotnog pada, te potom prevladavajuće stagnacije s dobi, a (2) kad test te boje ne sadrži, SSP pokazuje neznačajan trend prvotnog rasta, a potom stagnacije. No, za razliku od PESP i SSP pokazatelja, OSP-pokazatelj dinamike funkcioniranja SP odražava slične obrasce dobnih razlika kod operacionalizacije s prometno relevantnim bojama i bez njih (prvotni pad sa $20-29$ na 30-39 godina, zatim rast sa 30-39 na 40-49 godina, a potom nastaju manje razlike u trendovima - daljnji rast kod leksičke te ponovni pad kod obojene verzije testa).

Interpretaciju obrazaca dobnih promjena PESP, SSP i OSP za dvije različite vrste SP-operacionalizacija (s prometno relevantnim bojama i bez njih) logično je prvo provesti za SSP i OSP jer PESP u sebi barem dijelom sadrži ta dva pokazatelja pa njegovi obrasci dobnih razlika barem dijelom odražavaju obrasce dobnih razlika SSP i OSP indikatora. Prema dostupnim podacima, ne postoje istraživanja koja su se bavila ovisnošću dobnih promjena SSP i OSP o perceptivnim odrednicama interferencije koju pripadni sustav SP nastoji inhibirati, te se dobiveni podaci tretiraju kao prvi u području i u skladu s time tumače logično povezanim metodološkim i fenomenološkim činjenicama te širim relevantnim mehanizmima kognitivnog funkcioniranja.

S obzirom da djelovanje dobi na SSP nije dokazano, razlike u dobnim obrascima SSP za dvije operacionalizacije Stroop testa, na ovom uzorku ispitanika vjerojatno su posljedica narušenih pretpostavki za dvosmjernu ANOVA-u, a posebice nepouzdane procjene SSP na najmlađem uzrastu strojovođa testiranih obojenom verzijom testa koji sadrži svega 2 ispitanika. Naime, s obzirom na navedene potvrde empirijske valjanosti mjere SSP i druge dostupne podatke, može se samo špekulirati zašto prelaskom sa 20-
29 na 30-39 godina SSP pokazuje rast u Stroop zadatku koji odražava veću interferenciju, a pad u zadatku koji odražava manju interferenciju. Za dodatno tumačenje dobivenog interakcijskog učinka potrebno je istraživanje ponoviti na većem i dobno ujednačenom uzorku strojovođa.

Statistički isti obrasci dobnih promjena OSP, dobivenih na obojenoj i leksičkoj operacionalizaciji tog konstrukta, ukazuju kako starenje jednako djeluje na taj pokazatelj dinamike funkcioniranja SP, neovisno o tome koja je mjera SP korištena. S obzirom na činjenicu da su se dobne promjene OSP pokazale statistički značajnima, ovakav nalaz uglavnom nije u skladu s logičnim očekivanjem da sa starenjem OSP postupno i sve više opada kod onih zadataka SP koji generiraju veću interferenciju. Naime, nalazi prethodnih dvosmjernih ANOVA kod PESP i SSP ukazuju na veću interferenciju kod leksičke verzije testa, pa je bilo opravdano očekivati da će u toj verziji Stroop testa OSP sa starenjem jače opadati nego li u obojenoj verziji testa - što se nije dogodilo.

Tumačenje interakcijskog učinka dobi i vrste Stroop testa na PESP (tj. različite dobne promjene PESP za leksičku i obojenu verziju testa), slično kao i kod analognog interakcijskog učinka na SSP, teško je argumentirati bez ponavljanja istraživanja na većem i dobno ujednačenom uzorku strojovođa, prvenstveno zbog toga jer glavni učinak dobi kod PESP nije dokazan. Naime, ponovno je značajna razlika u obrascu dobnih promjena PESP kod leksičke i obojene verzije testa uzrokovana na isti način: porastom PESP u inhibicijskih zahtjevnijoj, te padom PESP u inhibicijski manje zahtjevnoj verziji Stroop testa, prelaskom sa 20-29 na 30-39 godina. Premda je MacLeod (1991.) ukazao kako u osnovi rješavanja različitih verzija Stroop testa stoje različiti inhibicijski mehanizmi - za koje se onda može pretpostaviti da pokazuju različite dobne promjene - trenutno nisu dostupni podaci koji bi tu razliku u dobnim promjenama korištene leksičke i obojene inačice objasnili. Argumentacija dobnog smanjenja impulzivnosti izlaskom iz razdoblja mladenaštva - koji se više očituje u testovima većih zahtjeva na inhibicijske mehanizme - funkcionira samo na razini špekulacije.

Konačno, može se postaviti pitanje zbog čega hrvatski strojovođe pokazuju veću PESP i 
SSP (a postoji i tendencija za veću OSP) u obojenoj, nego li u leksičkoj verziji testa? To pitanje nije uvršteno u hipoteze istraživanja zbog istraživačkog nacrta u kojem nije bilo moguće dovoljno kontrolirati uvjete ispitivanja za dvije skupine strojovođa, premda korištenje relativnih mjera PESP, SSP i OSP to donekle kompenzira. Jedan mogući odgovor na pitanje jest da precrtavanje naziva boje, odnosno riječi, generira manju interferenciju nego li precrtavanje ciljne boje $\mathrm{s}$ inkongruentnim značenjem pripadne riječi (MacLeod, 1991.), no postavlja se pitanje zašto analogija ne vrijedi i kod leksičke verzije (za odnos fizičke veličine riječi i značenja riječi)? Drugo moguće obrazloženje proizlazi iz odabira boja koje se koriste na obojenoj verziji Stroop testa. Naime, zelena i crvena boja često su korištene u prometnoj signalizaciji pa su one važne i vrlo poznate strojovođama. Njihova česta izloženost tim bojama može se promatrati kao vježba ili trening koji obično povećavaju uspješnost sustava SP, čak i kod starijih ljudi (Davidson et al., 2003., Popkin et al., 2008.), ali ovu argumentaciju treba uzeti s oprezom zbog već spomenutog nedostajanja kontrolne skupine muških "ne-strojovođa".

\section{Opravdanost korištenja PESP, SSP i OSP za opis dinamike funkcioniranja SP kod hrvatskih strojovođa}

Prethodno analizirana, teorijska i empirijska valjanost PESP, SSP i OSP, sa specifičnostima definicije, metrijskih obilježja te deskriptivnih statistika dobnih raspodjela, predstavlja preliminarnu potvrdu opravdanosti zasebnog korištenja navedena tri pokazatelja dinamike funkcioniranja SP. Naime, radi se o tri različito definirana konstrukta, s različitim operacionalizacijama, koje poprimaju teorijski očekivane vrijednosti na uzorku strojovođa, $\mathrm{i}$ to $\mathrm{s}$ raspodjelama koje ukazuju na dobra statistička i metrijska svojstva tih operacionalizacija.

Međusoban odnos tri pokazatelja može ukazivati na opravdanost njihova korištenja, ako se - pored drugih mjera valjanosti tih konstrukata dokaže da oni nisu visoko povezani. Međusobne korelacije PESP, SSP i OSP to i pokazuju (značajne su i niske samo između PESP i SSP), a njihove vrijednosti su teorijski očekivane: PESP bi trebao dijelom odražavati razvijenost SSP, a - u slučajevima prisutnost strategije brzog odgovaranja na račun točnosti - i razvijenost OSP. Kako izračunate korelacije (vidi Metoda) pokazuju da spomenuta strategija nije značajna, odnos PESP i OSP je teorijski očekivan.

Dobne promjene neovisne o perceptivnom sadržaju testa SP slične su - premda ne istovjetne - za PESP i SSP, dok su različite za OSP. Ta činjenica ukazuje na donekle različite mehanizme u osnovi dobnih promjena tri pokazatelja funkcioniranja SP, a time i u osnovi samih pokazatelja. Analogan obrazac, te zaključak, vidljivi su kod razmatranja dobnih promjena ovisnih o perceptivnom sadržaju testa SP: one su slične za PESP i SSP, a različite za OSP - što ponovno upućuje na donekle različite mehanizme u osnovi PESP, SSP i OSP te time opravdava korištenje tri, a ne samo jednog pokazatelja funkcioniranja SP za opis ovog kognitivnog podsustava hrvatskih strojovođa. Na isti zaključak upućuje i djelovanje perceptivnog sadržaja testa SP na PESP, SSP i OSP, neovisno o dobi jer je to djelovanje slično za PESP i SSP, a različito za OSP.

Korištenje tri novouvedena pokazatelja dinamike funkcioniranja sustava SP daje sveobuhvatniju sliku funkcioniranja tog sustava kod hrvatskih strojovođa nego kad bi se koristio samo uvriježeni indikator prosječnog funkcioniranja, a posebice u pogledu starosnih promjena. Praćenje učinaka starenja ovim pokazateljima omogućava bolji uvid u posljedice starenja, ali i u djelovanje mogućih intervencija kojima se te posljedice nastoje ublažiti. Tih intervencija je mnogo, od bioloških (upotreba suplementa leptina ${ }^{4}$ ima pozitivan utjecaj kod pacijenata s manjkom leptina na volumen sive tvari koja predviđa brzinu procesiranja); (Eckert, 2011.) do socijalnih (održavanje angažiranog i aktivnog životnog stila kod sudionika 70-103 godine može ublažiti pad u brzini procesiranja); (Lowden et al., 2005.). Trening brzine procesiranja dovodi do poboljšanja vidne pažnje i brže obrade podataka - što opet dovodi do manje opasnih manevara tijekom vožnje (Roenker et al., 2003.). Isti trening dovodi i do manje osobno izazvanih sudara kod vozača iznad 65 godina (Ball et al., 2010.).

${ }^{4}$ Leptin je regularni tjelesni hormon koji pomaže u regulaciji energetskog balansa tako što inhibira glad (Paz-Filo et al., 2015.). 
Konačno, Llaneras, Swezey, Brock, Rogers i Van Cott (1998.) pokazali su da i kompenzacijske intervencije i treninzi dovode do privremenih poboljšanja određenih perceptivnih, kognitivnih i psihomotornih sposobnosti, dok vozači koji koriste navigacijski sustav u vozilu, rade manje navigacijskih pogrešaka, pokazuju bolju prilagodbu brzine i bolju praćenu izvedbu.

\section{ZAKLJUČAK}

Nedostatni podaci o starosnim promjenama selektivne pažnje strojovođa (posebice hrvatskih) potaknuli su ovo istraživanje koje, ne samo da je uključilo više dobnih skupina i dvije operacionalizacije SP u odnosu na prethodna istraživanja, nego i dva dodatna pokazatelja funkcioniranja SP (SSP i OSP), pored prosječnog (PESP) - koji se uvriježeno koristi u istraživanjima dobnih razlika u SP opće populacije. PESP, SSP i OSP teorijski su utemeljene, a njihove vrijednosti dobivene na uzorku hrvatskih strojovođa empirijski potvrđuju valjanost pripadnih operacionalizacija, u onoj mjeri u kojoj je to omogućio istraživački nacrt. Imajući u vidu metodološka ograničenja tog nacrta (koja smanjuju pretpostavke za ANOVA-u, a posebice mali broj sudionika na pojedinim dobnim skupinama), očekivane nelinearne dobne promjene tih pokazatelja samo su dijelom potvrđene i, k tome, dijelom ovise o perceptivnom sadržaju testa SP (sadrže li prometno relevantne boje, ili samo leksičke podražaje): (1) samo jedan statistički test (od niza korištenih) potvrdio je tendenciju nelinearnog dobnog smanjenja PESP, koje je kod obojene verzije SP-testa bilo monotono, dok kod leksičke verzije testa nije bilo jasno izraženo (prvotni rast, potom stagnacija i pad) - što je proizvelo značajan interakcijski učinak dobi i vrste testa SP; (2) niti jedan statistički test nije dokazao značajan nelinearni pad SSP s dobi, već su zabilježene tendencije nelinearnih promjena, različite za obojenu verziju testa (prvotni izraženi pad i potom blagi rast) i leksičku verziju testa (prvotni rast i potom stagnacija) što je ponovno proizvelo značajan interakcijski učinak dobi i vrste testa SP; (3) nelinearne dobne promjene OSP jesu statistički potvrđene, ali uglavnom u neočekivanom smjeru (odražavaju porast OSP između dobnih skupina 30-39 i 4049), te se na sličan način odražavaju za obje ver- zije testa. Dobivene nalaze o učinku starenja i perceptivnog sadržaja testa teško je komentirati jer komparabilna istraživanja ne postoje niti u općoj populaciji, a kamo li u populaciji strojovođa. No, ona istraživanja koja se mogu bar djelomice dovesti u odnos s provedenim ukazuju da dobiveni nalazi nisu neočekivani. Objašnjivi nalazi različitih starosnih promjena PESP, SSP i OSP, empirijski potvrđen logičan međusobni odnos ta tri pokazatelja, te njihova teorijska utemeljenost i empirijske potvrde njihove valjanosti na uzorku strojovođa, jasno opravdavaju korištenje tih pokazatelja dinamike funkcioniranja SP u istraživanju starosnih promjena tog važnog kognitivnog sustava. Ti indikatori omogućuju i sveobuhvatno praćenje mogućih intervencija poduzetih da bi se ublažile posljedice starenja, ali i nepovoljnih radnih uvjeta hrvatskih strojovođa na funkcioniranje SP sustava koje mogu ugroziti sigurnost prijevoza robe i putnika. Ipak, kako bi se otkrili specifični mehanizmi odgovorni za dobnu deterioraciju SP kod strojovođa, potrebne su opsežnije studije s kontrolnom skupinom „ne-strojovođa“, probabilističkim uzorkom strojovođa (uključujući podgrupe s prekvalificiranim sudionicima i sudionicima oštećenog zdravlja), s mjerenjem okolinskih čimbenika, kao i s operacionalizacijama SP koje generiraju veću interferenciju, te dodatnim varijablama koje se odnose na zdravlje i životni stil strojovođa.

\section{LITERATURA}

Adleman, N.E. Chen, G., Reynolds, R.C., Frackman A., Razdan, V., Weissman, D.H., Pine, D.S., Leibenluft, E.: Age-related differences in the neural correlates of trial-to-trial variations of reaction time, Developmental Cognitive Neuroscience, 19, 2016., 248-257.

Ardila, A.: Normal aging increases cognitive heterogeneity: Analysis of dispersion in WAIS-III scores across age, Archives of Clinical Neuropsychology, 22, 2007., 8, 1003-1011.

Backman, A.L.: Health survey of professional drivers, Scandinavian Journal of Work, Environment \& Health, 9, 1983., 1, 30-35.

Ball, K.K., Edwards, J.D., Ross, L.A., McGwin, G.: Cognitive training decreases motor vehicle 
collision involvement in older driver, Journal of American Geriatric Society, 58, 2010., 11, 2107 2113.

Ben-David, B.M., Schneider, B.A.: A sensory origin for Color-Word Stroop effects in aging: A meta-analysis, Aging, Neuropsychology, and Cognition, 16, 2009., 5, 505-534.

Brink, J.M., McDowd, J.M.: Aging and selective attention: An issue of complexity or multiple mechanisms? Journal of Gerontology: Psychological Sciences, 54, 1999., 1, 30-33.

Broach, D., Joseph, K.M., Schroeder, D.J.: Pilot Age and Accident Rates Report 4: An Analysis of Professional ATP and Commercial Pilot Accident Rates by Age, Civil Aeromedical Institute, Human Resources Research Division, Oklahoma City, 2003., dostupno na: https://www.faa.gov/ data_research/research/med_humanfacs/age60/ media/age60_4.pdf, pristupljeno: 27.03.2017.

Castellanos, F.X., Sonuga-Barke, E.J.S., Scheres, A., Di Martino, A., Hyde, C., Walters, J.R.: Varieties of attention-deficit/hyperactivity disorder-related intra-individual variability, Biological Psychiatry, 57, 2005., 11, 1416-1423.

Christ, S.E., White, D.A., Mandernach, T., Keys, B.A.: Inhibitory control across the lifespan, Developmental Neuropsychology, 20, 2001., 3, 653-669.

Coyle, T. R.: A review of the worst performance rule: Evidence, theory, and alternative hypotheses, Intelligence, 31, 2003., 567-587.

Davidson, J.D., Zacks, R.T., Williams, C.C.: Stroop interference, Practise and Aging, Neuropsychology, development, and cognition. Section B, Aging, neuropsychology and cognition, 10, 2003., 2, 85-98.

Drenovac, M.: Kronometrija dinamike mentalnog procesiranja, Filozofski fakultet Sveučilišta J.J. Strossmayer, Osijek, 2009.

Drenovac, M., Drenovac, S.: Trajanje radnog vremena i promjene u radnoj sposobnosti strojovođa dizel i elektro lokomotiva, Čovjek i promet, 2, 1976., 3, 223-229.

Drenovac, M., Drenovac, S.: Karakteristike kompleksnog vremena psihomotorne reakcije zatvorenika - saobraćajnih delikvenata, VII. Dani psihologije u Zadru, 5, 1989a., 113-117.

Drenovac, S., Drenovac, M.: Kolebanje učinka dispečera u rješavanju mentalnih i psihomotornih zadataka tokom dnevne i noćne 12-satne smjene, Čovjek i promet, 15, 1989b., 3, 115-127.

Eckert, M. A.: Slowing down: age-related neurobiological predictors of processing speed, Frontiers in Neuroscience, 5, 2011., 1-13.

Hartley, A.: Evidence for the selective preservation of spatial selective attention in old age, Psychology and Aging, 8, 1993., 3, 371-319.

Jensen, A.R.: Clocking the mind: Mental chronometry and individual differences, Elsevier Ltd., Oxford, UK, 2006.

Jensen, A.R., Rohwer, W.D.: The Stroop color-word test: A review 1, Acta Psychologica, 25, 1966., 1, 36-93.

Kanfer, R., Ackerman, P.L.: Aging, adult development, and work motivation, Academy of Management Review, 29, 2004., 3, 440-458.

Llaneras, R.E., Swezey, R.W., Brock, J.F., Rogers, W.C., Van Cott, H.P.: Enhancing the safe driving performance of older commercial vehicle drivers, International Journal of Industrial Ergonomics, 22, 1998., 3, 217-245.

Lowden, M., Ghisletta, P., Lindenberger, U.: Social participation attenuates declines in perceptual speed in old and very old age, Psychology and aging, 20, 2005., 3, 423-434.

Ludwig, C., Borella, E., Tettamanti, M., de Ribaupierre, A.: Adult age differences in the Color Stroop Test: A comparison between an Item-byitem and Blocked version, Archives of Gerontology and Geriatrics, 51, 2010., 2, 135-142.

Lutz, A., Slagter, H.A., Rawlings, N.B., Francis, A.D., Greischar, L.L., Davidson. R.J.: Mental training enhances attentional stability: neural and behavioural evidence, The Journal of Neuroscience, 29, 2009., 42, 13418-13427.

MacDonald, S.W.S., Hultsch, D.F., Dixon, R.A.: Performance variability is related to change in cognition: Evidence from the Victoria Longitudinal Study, Psychology and Aging, 18, 2003, 3, 510-523.

MacLeod, C.M.: Half a century of research on the Stroop Effect: An Integrative Review, Psychological Bulletin, 109, 1991., 2, 163-203.

MacLeod, C.: Training on integrated versus separated Stroop tasks: The progression of interference and facilitation, Memory and Cognition, 26, 1998., 2, 201-211.

Madden, D.J., Langley, L.K.: Age-related changes in selective attention and perceptual load 
during visual search, Psychology and Aging, 18, 2003., 1, 54-67.

McGaughy, J., Eichenbaum, H.: It is time to pay attention to attention in aging, Learning and Memory, 9, 2002., 4, 151-152.

Mutter, S.A., Naylor, J.C., Patterson, E.R.: The effects of age and task context on Stroop task performance, Memory \& Cognition, 33, 2005., 3, 514-530.

Myerson, J., Robertson, S., Hale, S.: Aging and intraindividual variability in performance: Analyses of response time distributions. Journal of Experimental Analysis of Behavior, 88, 2007., 3, 319-337.

Paz-Filo, G., Mastronadi, C.L., Licinio, J.: Leptin treatment: facts and expectations, Metabolism, 64, 2015., 1, $146-156$.

Popkin, S.M., Morrow, S.L., Di Dimenico, T.E., Howarth, H.D.: Age is more than just a number: Implications for aging workforce in the US transportation sector, Applied Ergonomics, 39, 2008., 5, 542-549.

Pravilnik o ovlaštenju strojovođa [Regulation on Railroad Engineer Licence]. Narodne novine [Official Gazette], 96/2013, 74/2015.

Rimac, I., Žebec, M.S., Jurić, D.: Verbal Uncolored Paper-and-Pencil Version of the Stroop Test - Metric Properties, 2006., dostupno na: https:// biblio.irb.hr/prikazi-rad?\&rad=276661, pristupljeno: 05.02.2016.

Roenker, D.L., Cissell, G.M., Ball, K.K., Wadley, V.G., Edwards, J.D.: Speed-of-processing and drivingsimulator training results in improved driving performance, Human Factors, 45, 2003., 2, 218-233.

Ryan, G.A., Legge, M., Rosman, D.: Age Related Changes in Drivers' Crash Risk and Crash Type, Accident Analysis \& Prevention, 30, 1998, 3, 379-387.

Salthouse, T.A., Davis, H.P.: Organization of cognitive abilities and neuropsychological variables across the lifespan, Developmental Review, 26, 2006., 1, 31-54.
Salthouse, T.A., Pink, J.E., Tucker-Drob, E.M.: Contextual analysis of fluid intelligence, Intelligence, 36, 2008., 5, 464-486.

Span, M.M., Ridderinkhof, K.R., van der Molen, M.W.: Age-related changes in the efficiency of cognitive processing across the life span, Acta Psychologica, 117, 2004., 2, 155-183.

Sternberg, R.J.: Kognitivna psihologija, Naklada Slap, Jastrebarsko, 2005.

Taylor, A.H., Dorn, L.: Stress, Fatigue, Health and Risk of Road Traffic Accidents Among Professional Drivers: The contribution of physical inactivity, Annual Review of Public Health, 27, 2006., 371-391.

West, R., Alain, C.: Age-related decline in inhibitory control contributes to the increased Stroop effect observed in older adults, Psychophysiology, 37, 2000., 1, 179-189.

West, R., Murphy, K.J., Armilio, M.R., Craik. F.I.M., Stuss, D.T.: Lapses of Intention and Performance Variability Reveal Age-Related Increases in Fluctuations of Executive Control, Brain and Cognition, 49, 2002., 402-419.

Woodson, W. E., Tillman, B., Tillman, P.: Human Factors Design Handbook, Second Edition, McGraw-Hill, Inc., 1992.

Žebec, M.S.: A contribution to the analysis of human speed of information processing: Developmental and differential arguments, Društvena istraživanja, 13, 2004., 1-2, 267-292.

Žebec, M.S., Budimir, S., Merkaš, M., Szirovicza, L., and Živičnjak, M.: Sex-specific agerelated changes of information processing rate indicators during childhood and adolescence, Collegium Antropologicum, 38, 2014., 2, 397408.

Žebec, M.S., Crnko, I., Sumpor, D.: Selective attention of Croatian railroad engineers from 25 to 59 years of age: Empirical findings and implications. U: Book of Proceedings of the $6^{\text {th }}$ International Ergonomics Conference, HED - Hrvatsko ergonomsko društvo, Zagreb, 2016. 


\section{INDICATORS OF SELECTIVE ATTENTION FUNCTIONING DYNAMICS ON THE SAMPLE OF CROATIAN RAILROAD ENGINEERS AND RELATED AGE DIFFERENCES}

SUMMARY: Research that focuses on aging process of selective attention (SA) functioning dynamics is very rare, especially regarding the professional drivers' population. Given the fact that the consequences of SA functioning in railroad engineers are extremely high for traffic safety, we considered it important to investigate the aging effects on three indicators of SA system functioning dynamics (average efficiency, stability and resilience to the adverse factors effects) with regard to different measures of SA. The study was conducted using two time limited forms of Stroop tests: the first - verbal, uncoloured (lexical) and the second - verbal, coloured paper-pencil form. Both forms were comprised of two parts/components: with incongruent stimuli (measuring SA and processing speed, i.e. PS) and neutral stimuli (measuring only PS). The participants were male railroad engineers, ages 25 to 59, unevenly distributed into 4 age categories distinguished by specific functional characteristics of professional drivers. 50 subjects completed the first test form and 52 the second. The subjects' task was to cross out as many of the target words in the distractors context in 60 seconds as possible (whereby the distraction was more intense for the incongruent stimuli). All three indicators of SA functioning dynamics are expressed as composites of objective measures of the Stroop test components. They show an unambiguous relation to the magnitude of the associated construct, while low inter-correlations indicate their diversity. With the exception of the relative position of the first test mistake - that could not be used as a measure of resilience due to the extremely small variability - in the selected sample of Croatian railroad engineers most of the other SA dynamic indicators show good statistical features and theoretical merits. Age related changes of the three SA dynamic indicators reflect a non-linear trend that is only partly in line with the expectations, while statistically significant only for SA resilience in the coloured version of the Stroop test. Although these age-related trends were mainly non-significant, average SA efficiency and stability in the coloured version of the test showed significantly different age-related changes in comparison to the lexical version of the test. Additionally, analyses have shown that the average SA efficiency is significantly higher in Stroop test that includes traffic relevant colours, while SA stability and resilience to the adverse factors effects show similar, although not significant, trend. The findings are - with a certain caution related to the lack of control group measurement and other methodological confinements specific for applied research - interpreted by specific railroad engineers experience and are discussed in relation to the theory of cognitive aging in the general population with the implications on the railroad engineers aging process and its consequences - especially regarding traffic safety.

Key words: selective attention, functioning dynamic indicators, aging process, railroad engineers 